\title{
Assessment of Surface Water Quality of Bétaré-Oya Gold Mining Area (East-Cameroon)
}

\author{
Felaniaina Rakotondrabe ${ }^{1,2 *}$, Jules Remy Ndam Ngoupayou ${ }^{1}$, Zakari Mfonka, \\ Eddy Harilala Rasolomanana ${ }^{2}$, Alexis Jacob Nyangono Abolo', Banakeng Lucian Asone', \\ Andrew Ako Ako 3 , Miora Harivony Rakotondrabe ${ }^{2}$
}

\footnotetext{
${ }^{1}$ Department of Earth Sciences, Faculty of Science, University of Yaoundé 1, Yaoundé, Cameroon

${ }^{2}$ Department of Mines, Advanced School of Engineering of Antananarivo, University of Antananarivo, Antananarivo, Madagascar ${ }^{3}$ Institute of Geological and Mining Research (IRGM), Hydrological Research Centre, Yaoundé, Cameroon

Email: ^rak.fleur@gmail.com, ^rakotondrabe@uy1.uninet.cm
}

How to cite this paper: Rakotondrabe, F., Ngoupayou, J.R.N., Mfonka, Z., Rasolomanana, E.H., Abolo, A.J.N., Asone, B.L., Ako, A.A. and Rakotondrabe, M.H. (2017) Assessment of Surface Water Quality of Bétaré-Oya Gold Mining Area (East-Cameroon). Journal of Water Resource and Protection, 9, 960984.

https://doi.org/10.4236/jwarp.2017.98064

Received: May 16, 2017

Accepted: July 4, 2017

Published: July 7, 2017

Copyright $\odot 2017$ by authors and Scientific Research Publishing Inc. This work is licensed under the Creative Commons Attribution International License (CC BY 4.0).

http://creativecommons.org/licenses/by/4.0/

\begin{abstract}
To assess the water quality in the locality of Bétaré-Oya affected by an intensive artisanal and semi mechanized mining activities, 71 samples were collected from sixteen points during the 2015-2016 hydrological year. These points include: three in Lom river which is the main stream of the study area, five in Mari river which is one of the left bank tributaries of the Lom, in Bétaré-Oya and eight in the left and the right bank of Mari. Different physicochemical parameters such as $\mathrm{pH}$, electrical conductivity (EC), alkalinity, turbidity, total suspended solids (TSS), cyanide $\left(\mathrm{CN}^{-}\right)$, major elements and heavy metals $(\mathrm{Pb}, \mathrm{Zn}, \mathrm{Cd}, \mathrm{Fe}, \mathrm{Cu}, \mathrm{As}, \mathrm{Mn}$ and $\mathrm{Cr}$ ) were analyzed. Water Quality Indices (WQI), Heavy metal Pollution Index (HPI), sodium adsorption ratio (SAR) and percent sodium ( $\mathrm{Na} \%$ ) were also computed to evaluate the suitability of water for drinking and irrigation. The results showed that the surface water from Bétaré-Oya was acidic to basic $(5.40<\mathrm{pH}<8.84)$, weakly mineralized $(11.60<\mathrm{EC}<122.10 \mu \mathrm{S} / \mathrm{cm})$ with a high concentration of TSS (2 $<$ TSS $<8996.00 \mathrm{mg} / \mathrm{L}$ ) and turbidity (1.22 to $4758.00 \mathrm{NTU})$. The WQI scores show excellently to unsuitable quality in almost all the sampling sites. The water quality is found to be most deteriorated in Lom river and in the downstream of Mari river where an extensive mining activity is carried out, with the high WQI value of 5137.40. Based on heavy metal pollution index, the mean value was 1195.36 and thus under the critical pollution index. We thus notice a serious physical degradation by organic and mineral suspended particles as well as chemical degradation by heavy metals. This results from mining activities in the Lom river and its main tributaries such as the Mari river in the upstream part of the Sanaga basin. According to the percentage of sodium and SAR, these waters can be used for irrigation purposes in almost all types of soils.
\end{abstract}




\section{Keywords}

Bétare-Oya in East Cameroon, Hydrochemistry, Gold Mining, Water Quality Index, Heavy Metal Pollution Index

\section{Introduction}

In Cameroon, surface water resources (streams, lakes, swamps) play a very vital role in the economy of this country since it is used for drinking, domestic activities, agriculture (irrigation), industries, hydroelectricity, mining activities, fishing, tourism and leisure [1] [2]. Concerning water supply, it is mostly done by tapping at water points (taps, wells and boreholes) in rural areas especially in the northern part of Cameroon essentially made up of sedimentary formations. This is the contrary in the southern part particularly in urban areas, mostly made up of basement formations, where water tapping is mainly done by capturing of surface water, followed by their physical and chemical treatment as well as water from boreholes. However, these surface waters regularly experience a quantitative and qualitative deterioration due to human activities (urbanization, agriculture, industries and mining activities), to which can be added the phenomenon of climate change/variability [3] [4] [5]. Among these human activities, a more attention will be laid on the impact of mining on water resources, particularly on surface water.

As in most developing countries, Cameroon has experienced a great progress in mining, mainly in the Adamaoua and East regions (Batouri, Colomines, Yokadouma, Meiganga and Bétaré-Oya) [6] [7]. In the latter, gold-bearing sites are exploited in an artisanal to semi-mechanized manner, thus predisposing the surface water to serious environmental pollution [6] [7].

Most studies in the East region have mainly concerned rocks, soils and gold mineralization [8] [9] [10]. No studies exist yet on water resource quality in relation to mining activities in this area. The aim of the present study is to assess surface water quality in the Bétaré-Oya gold mining area (East Cameroon) through hydrochemical analyses using water quality indices (WQI) and heavy metal pollution index. Water quality index (WQI) is an effective technique for assessing drinking water quality suitability in any area [11] [12]. Heavy metal pollution index (HPI) is used to evaluate the hazardous metal pollution in drinking water [13] [14]. The Betaré-Oya site retained for this study is found to the north of the Lom-Pangar dam at the upstream part of the Sanaga basin (the largest and most important basin in Cameroon with a surface area of 133,000 $\mathrm{km}^{2}$ ). The solid, liquid, physical and chemical waste resulting from artisanal and semi-mechanized exploitation of gold deposits in the area could lead to the degradation of the quality of water in the Sanaga, and could have a negative impact on the rich aquatic fauna of this ecosystem, on the project of supplying potable water for the inhabitants of Yaounde tapped at Batschenga. This therefore induces us to carry out a study in this regard. 


\section{Materials and Methods}

\subsection{Study Area}

The Bétaré-Oya gold district is located in the Sanaga basin between latitudes $5^{\circ} 30$ '07" and $5^{\circ} 46^{\prime} 01^{\prime \prime}$ North, and longitudes $14^{\circ} 04^{\prime} 04^{\prime \prime}$ and $14^{\circ} 28^{\prime} 06^{\prime \prime}$ East (Figure 1). The study area varies from $665 \mathrm{~m}$ to $1050 \mathrm{~m}$ altitude. The climate is a typical equatorial transition type, characterized by two seasons consisting of a long rainy season from March to November, a short dry season from December to February. The hydrologic regime of the river Lom in Bétaré-Oya is controlled by rainfall, the lowest monthly flow rate is observed in February $\left(56 \mathrm{~m}^{3} / \mathrm{s}\right)$, while the maximum flow rate is observed in October $\left(328 \mathrm{~m}^{3} / \mathrm{s}\right)$. In the $2015-2016$ hydrologic year, the mean annual flow rate was $150 \mathrm{~m}^{3} / \mathrm{s}$, corresponding to a specific discharge of 13.50 $1 / \mathrm{s} / \mathrm{km}^{-2}$. This corresponds to runoff which flows at $397.55 \mathrm{~mm}$ for a flow coefficient of 28\%; with an average annual rainfall of $1440 \mathrm{~mm}$. The average inter-annual temperature is $24.58^{\circ} \mathrm{C}$. The hottest month is March with an average temperature of $26.00^{\circ} \mathrm{C}$ and the coldest month is in July $\left(23.50^{\circ} \mathrm{C}\right)$.

\subsection{Geological Setting}

Bétaré-Oya belongs to the Panafrican belt of Cameroon, limited to the North by the Adamawa shear zone and to the South, by the Sanaga shear zone [15] [16].
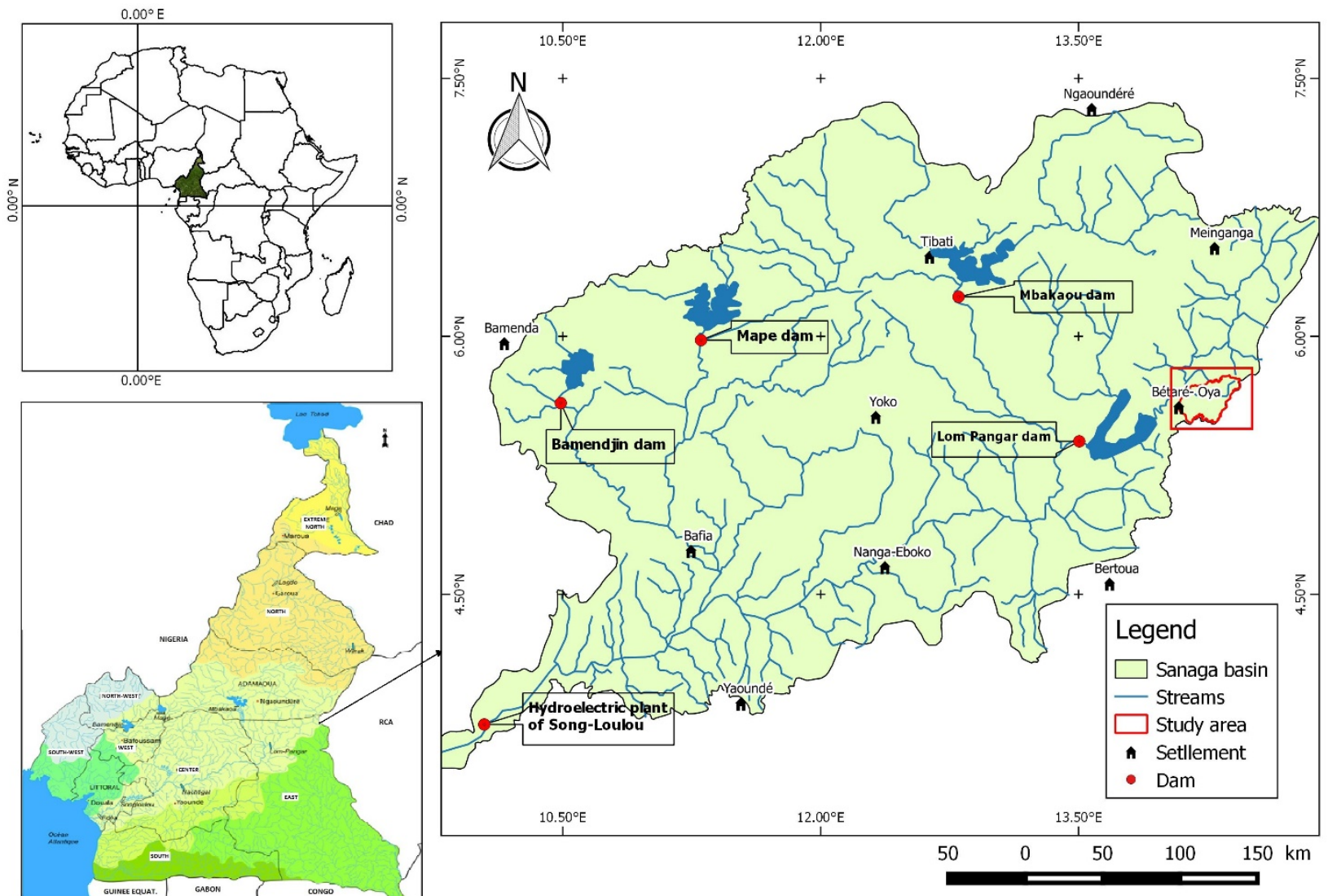

Figure 1. Location of the study area in the Sanaga basin. 
The geological formations are dominated by meta-sedimentary rocks, metavolcanics and intrusive granites known as the "Lom series" [17]. They consist of schists, micaschists, orthogneiss of Wakaso and Ndokayo, quartzites, cross-cut by Pan-African granitoids and conglomerates of Mari, post-tectonic granite of Ngibi and Kongolo (Figure 2) [18] [19]. These lithological units have a NE-SW steeply dipping foliation reflecting a dextral and senestral shear direction that is related to the central shear zone of Cameroon [19]. The Lom series is also well known for its gold mineralization as well as other minerals associated with granitic intrusions such as $\mathrm{Pb}, \mathrm{Bi}$ and $\mathrm{Mo}$ [20] [21]. Two types of gold mineralization are known in Bétaré-Oya [16]: (1) mineralization in quartz veins associated with pyrite and (2) alluvial and eluvial deposits, which have been intensively exploited in the area. The latter are located in the flats of the River Lom and its tributaries such as Mari, Nakoyo, Mbal. The geological formations of Bétaré-Oya are overlain mainly by thick ferrallitic soils with brown or red color. Hydromorphic soils occur in marshy areas as well as alluvial flats and the dark color on the upper part of the profile is indicative of the abundance of organic matter [22].

\subsection{Sampling and Analytical Procedure}

The river Lom and some of its tributaries (Mari, Mbal, Nakoyo) drain the vast majority of the Bétaré-Oya mining sites. In the present study, sampling was carried out in the Lom, Mari and some of its tributaries which drains a representative area of all the mining sites in the locality. Sixteen sampling points were identified in Lom River and the Mari River and its tributaries. The points include:
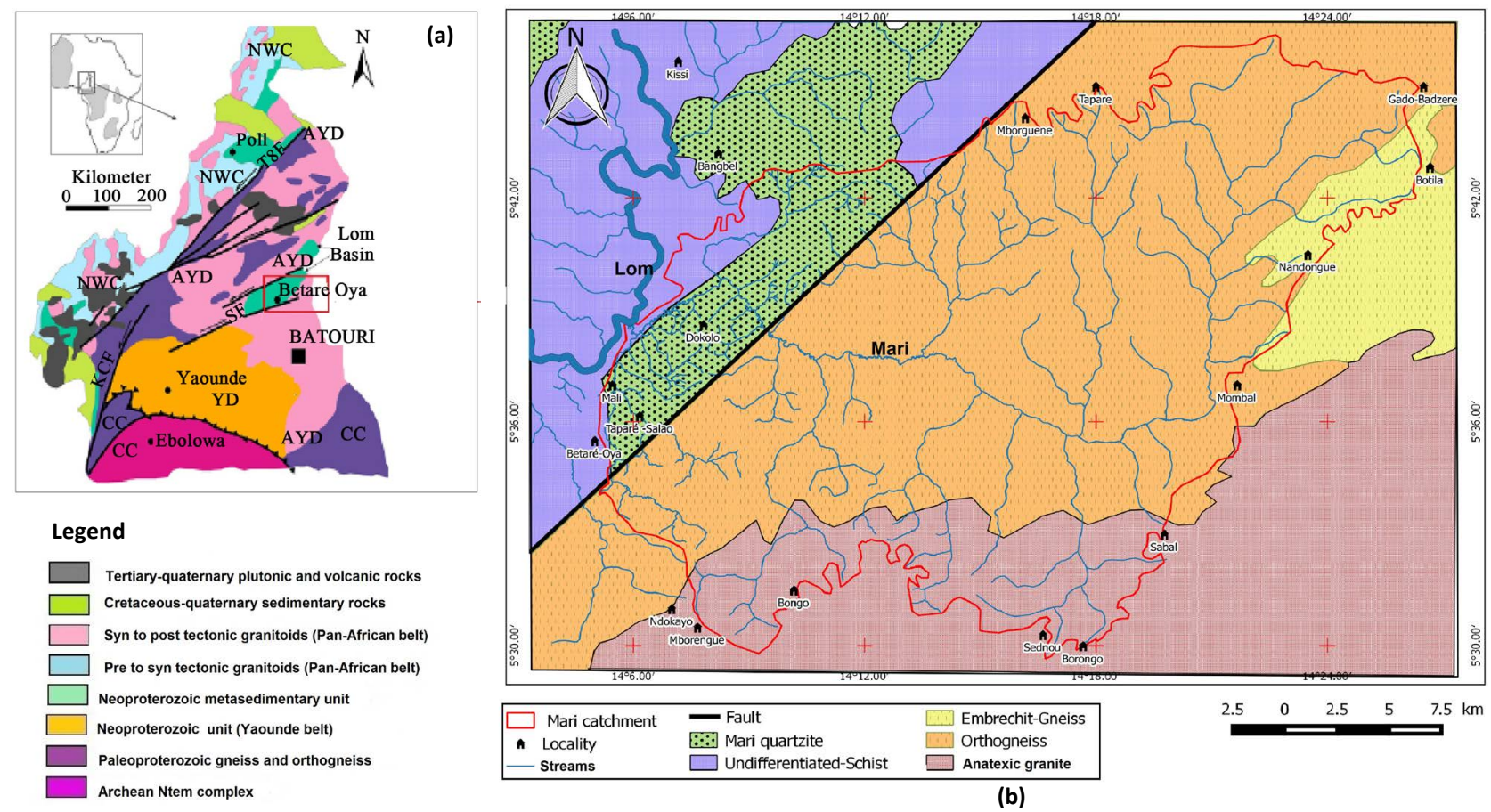

Figure 2. Geological map of Cameroon (modified after [10] [21]; (b) Regional geological map of Bétaré-Oya (modified after [15])). 
three on the Lom River, five points on the main Mari River, three and five points respectively on the left and right bank of Mari (Table 1). These points were identified using Global Positioning System (GPS) materialized on a SRTM satellite image with $30 \mathrm{~m}$ of resolution (Figure 3). All these points were selected based on criteria such as accessibility and their proximity or not in the vicinity of the mining sites. All of the sixteen sample points were used for physicochemical analysis (EC, turbidity, TSS, $\mathrm{Na}^{+}, \mathrm{NH}_{4}^{+}, \mathrm{K}^{+}, \mathrm{Mg}^{2+}, \mathrm{Ca}^{2+}, \mathrm{HCO}_{3}^{-}, \mathrm{Cl}^{-}, \mathrm{F}^{-}, \mathrm{NO}_{3}^{-}$, $\mathrm{PO}_{4}^{3-}, \mathrm{SO}_{4}^{2-}$ ) and four of them were selected for the control of heavy metals and cyanide. This includes two points of the Mari River and it right bank $\left(\mathrm{MMR}_{3}\right.$, $\left.\mathrm{MMR}_{5}\right)$ and two points from the Lom River $\left(\mathrm{LOM}_{2}, \mathrm{LOM}_{3}\right)$. These points are either located close to the mining sites or around the area where washing and panning is carried out. A total of 71 samples were collected from April 2015 to February 2016, taking into account the different seasons of the hydrological year of the study area.

Samples were collected manually once time at $<1 \mathrm{~m}$ depth at the centre of the river preferentially where the flow velocity was high enough to allow a good homogenization of the solid particles and dissolved materials [5]. The samples were collected in $1.5 \mathrm{~L}$ polyethylene bottles washed with ultrapure acid, previously rinsed with distilled and MilliQ deionized waters, and finally rinsed three

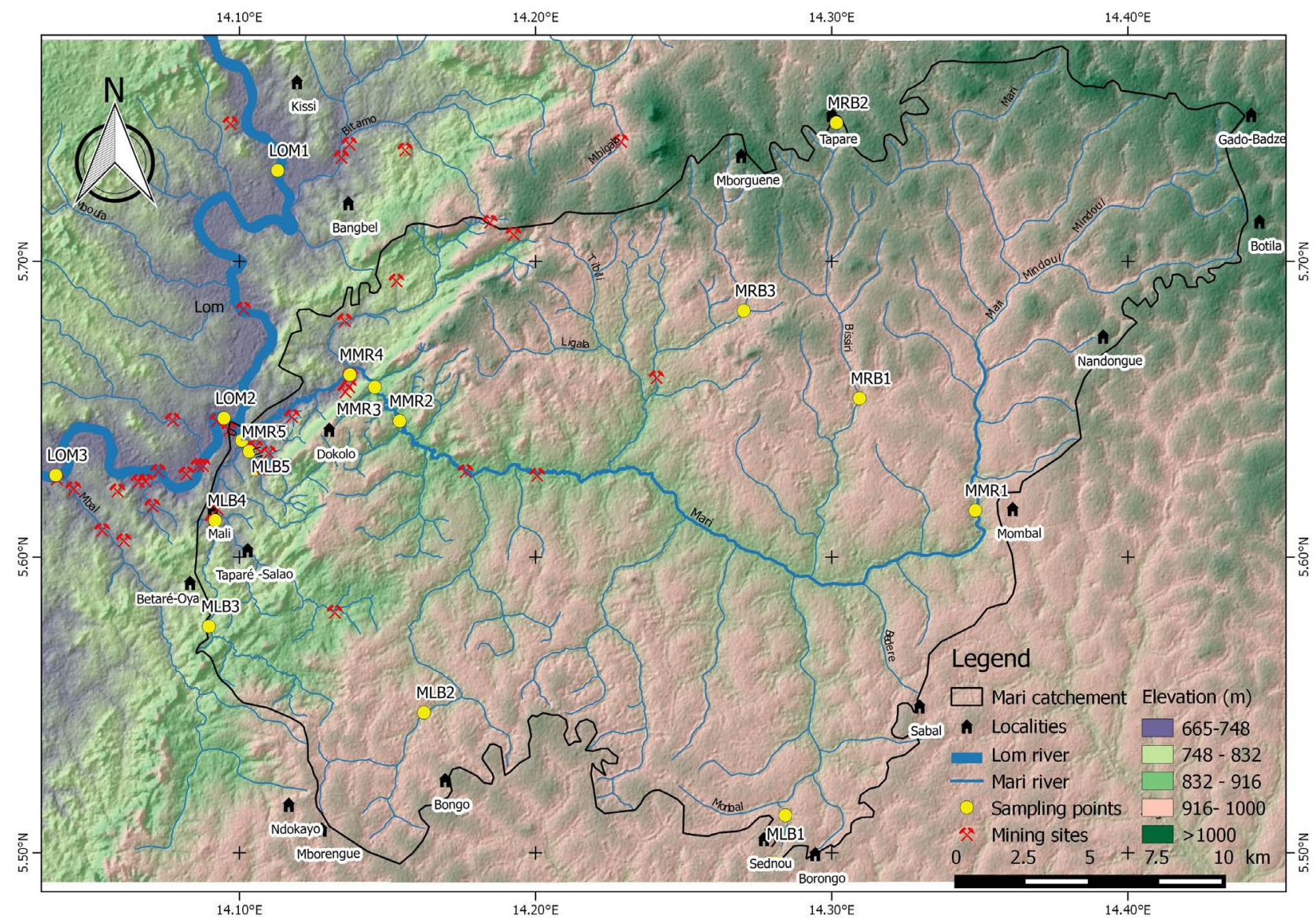

Figure 3. DEM map of Bétayé-Oya showing sampling points in the Lom River, Mari and its tributaries as well as the mining sites of the locality. 
Table 1. Geographical coordinates of the sixteen sample points.

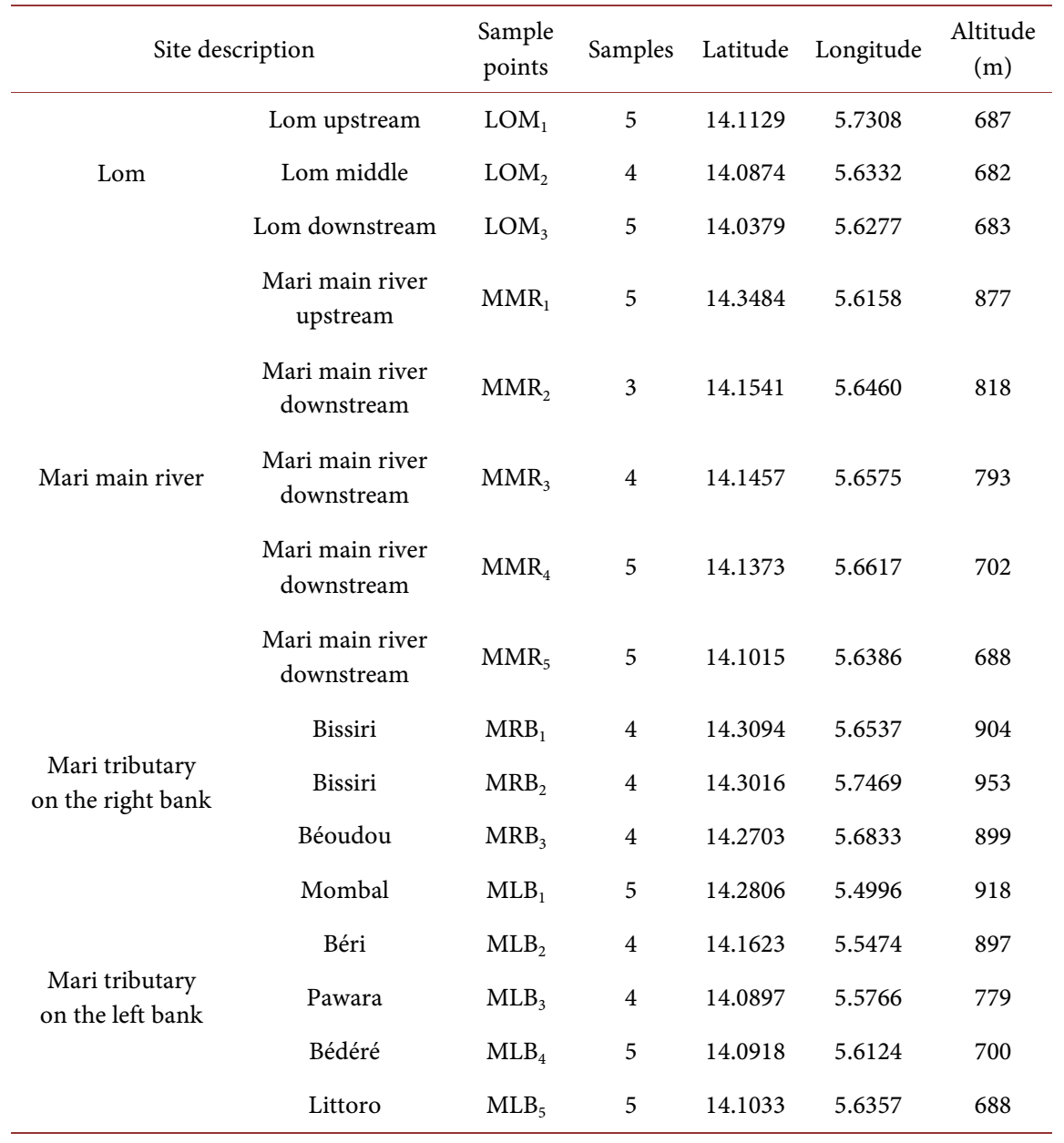

times with sampling water according to standard procedures [23] [24].

Some in-situ parameters such as $\mathrm{pH}$, electrical conductivity (EC) were measured on unfiltered water using calibrated WTW $315 \mathrm{i}$ instruments. The samples for trace elements analysis were filtered on-site through filters on acetate cellulose $0.45 \mu \mathrm{m}$ into $250 \mathrm{ml}$ polyethylene bottle and immediately acidified to $\mathrm{pH}<2$ with ultrapure nitric acid. All samples were stored in an ice-chest at temperature less than $4^{\circ} \mathrm{C}$ until they were transported to the laboratories in Yaoundé (Cameroon) and analyzed within ten days. Chemical analyses of water samples were performed in the Laboratory of Geochemical and Water Analysis (LAGE) at Nkolbisson (Cameroon). The major cations $\left(\mathrm{Na}^{+}, \mathrm{NH}_{4}^{+}, \mathrm{K}^{+}, \mathrm{Mg}^{2+}, \mathrm{Ca}^{2+}\right)$ was performedby Dionex ICS-90 ion chromatography and major anions $\left(\mathrm{Cl}^{-}, \mathrm{F}^{-}\right.$, $\mathrm{NO}_{3}^{-}, \mathrm{PO}_{4}^{3-}, \mathrm{SO}_{4}^{2-}$ ) by Dionex ICS-1100 ion chromatography. The turbidity was measured using the turbid meter 966 Orbeco Hellige model. Alkalinity was measured by automatic titration 862 Compact Metrohm model. Total suspended solids (TSS) were obtained by filtration and weighing. The ultrapure water (MQ) with the resistivity of $18.2 \mathrm{M} \Omega \cdot \mathrm{cm}$ was used for all analyses also used as blank. Reagent and procedural blanks were determined in parallel to the sample treatments using identical procedures. Each calibration curve was evaluated by ana- 
lyses of the quality control standards before, during and after the analyses of a set of samples. The chemical results were only accepted when the charge balance error was within $\pm 5 \%$. The essential trace metals $(\mathrm{Cr}, \mathrm{Cd}, \mathrm{Zn}, \mathrm{Fe}, \mathrm{Cu}, \mathrm{Pb}, \mathrm{As}$, $\mathrm{Mn})$ and $\mathrm{CN}^{-}$, were determined using MACHEREY-NAGEL photometric method at the "Cabinet de étude SOS environement" in Soa, Cameroon. Arsenic was determined by Quantofix method, $\mathrm{Pb}$ and $\mathrm{Cd}$ by Nanocolor and $\mathrm{Cu}, \mathrm{Zn}, \mathrm{Cr}, \mathrm{Mn}$, $\mathrm{Fe}$ and $\mathrm{CN}^{-}$by Visocolor ECO.

\subsection{Data Management}

Data obtained in this study was processed using standard method of hydrochemistry (Diagram software) and the calculation of Water Quality Index (WQI) and Heavy Metal Pollution Index (HPI). The parameters such as SAR and percent sodium ( $\mathrm{Na} \%)$ were also calculated to evaluate the suitability of the water quality for agricultural purposes.

\subsubsection{Calculation of Water Quality Index (WQI)}

Initially, water quality index (WQI) was developed by [25] in United States by selecting 10 most commonly used water quality variables like dissolved oxygen (DO), $\mathrm{pH}$, coli forms, specific conductance, alkalinity and chloride etc. and has been widely applied and accepted in European, African and Asian countries [26] [27]. Furthermore, a new WQI similar to Horton's index has also been developed by the group of Brown et al., (1970) and then by Cude, (2001) which was based on weights to individual parameter [26]. The WQI, which is considered to be a powerful tool that can present a comprehensive picture of river water quality, is the rate that reflects the integrated impact of different water quality variables [11] [12]. It is calculated as follows: each chemical parameter was assigned different weights $\left(w_{i}\right)$ in a scale of 1 (least effect on water quality) to 5 (highest effect on water quality) based on their perceived effects on primary health and according to its relative importance in the drinking water quality. The highest weight of 5 was assigned to parameters that have critical health effects and whose presence above the critical concentration limits could limit the usability of the resource for domestic and drinking purposes $\left(\mathrm{NO}_{3}^{-}\right)$; the minimum weight of 1 was assigned to $\mathrm{K}^{+}$because of its insignificant role in water quality assessment. Other parameters such as $\mathrm{pH}, \mathrm{EC}$, TSS, turbidity, $\mathrm{HCO}_{3}^{-}$, $\mathrm{Cl}^{-}, \mathrm{SO}_{4}^{2-}, \mathrm{F}^{-}, \mathrm{Ca}^{2+}, \mathrm{Mg}^{2+}$, were assigned weights between 2 and 4 based on their relative significance in the water quality evaluation. The relative weight $\left(W_{i}\right)$ is computed from the following equation:

$$
W_{i}=w_{i} / \sum_{i=1}^{n} w_{i}
$$

where, $W_{i}$ is the relative weight, $w_{i}$ is the weight of each parameter, and $n$ is the number of parameters. The calculated relative weight $\left(W_{i}\right)$ values of each parameter are given in Table 2 .

The quality rating $\left(q_{i}\right)$ for each parameter is assigned by dividing its concentration in each water sample by its limits values given by the WHO (2011) [28] 
Table 2. Relative weight of chemical parameters.

\begin{tabular}{ccccc}
\hline Parameters & Unit & WHO standards (2011) & Weight (wi) & Relative weight (wi) \\
\hline $\mathrm{pH}$ & & $6.5-8.5$ & 4 & 0.105 \\
$\mathrm{EC}$ & $\mathrm{HS} / \mathrm{cm}$ & 1400 & 4 & 0.105 \\
$\mathrm{TSS}$ & $\mathrm{mg} / \mathrm{L}$ & $25-40$ & 2 & 0.053 \\
$\mathrm{Turb}$ & $\mathrm{NTU}$ & 5 & 2 & 0.053 \\
$\mathrm{Na}^{+}$ & $\mathrm{mg} / \mathrm{L}$ & 200 & 2 & 0.053 \\
$\mathrm{~K}^{+}$ & $\mathrm{mg} / \mathrm{L}$ & 12 & 1 & 0.026 \\
$\mathbf{M g}^{2+}$ & $\mathrm{mg} / \mathrm{L}$ & 125 & 2 & 0.053 \\
$\mathbf{C a}^{2+}$ & $\mathrm{mg} / \mathrm{L}$ & 75 & 2 & 0.053 \\
$\mathbf{F}^{-}$ & $\mathrm{mg} / \mathrm{L}$ & 1.5 & 4 & 0.105 \\
$\mathbf{C l}^{-}$ & $\mathrm{mg} / \mathrm{L}$ & 250 & 3 & 0.079 \\
$\mathbf{N O}_{3}^{-}$ & $\mathrm{mg} / \mathrm{L}$ & 50 & 5 & 0.132 \\
$\mathbf{S O}_{4}^{2-}$ & $\mathrm{mg} / \mathrm{L}$ & 250 & 4 & 0.105 \\
$\mathbf{H C O}_{3}^{-}$ & $\mathrm{mg} / \mathrm{L}$ & $125-130$ & 3 & 0.079 \\
& & & $\sum w_{i}$ & $\sum w_{i}=1.000$ \\
& & & &
\end{tabular}

and the result multiplied by 100 .

$$
q_{i}=\left(\frac{C_{i}}{S_{i}}\right) \times 100
$$

where, $q_{i}$ is the quality rating, $C_{i}$ is the concentration of each chemical parameter in each water sample in $\mathrm{mg} / \mathrm{L}$, and $S_{i}$ is the drinking water standard for each chemical parameter in milligrams per liter according to the guidelines of the WHO (2011).

To calculate $W Q I, S I_{i}$ value should be determined with the following equations:

$$
\begin{aligned}
S I_{i} & =W_{i} \times q_{i} \\
W Q I & =\sum_{i=1}^{n} S I
\end{aligned}
$$

where, $S I_{i}$ is the sub-index of $I^{\text {th }}$ parameter; $q_{i}$ is the quality rating based on concentration of $i^{\text {th }}$ parameter [11]. The computed $W Q I$ values are classified into five categories as follows (Table 3).

\subsubsection{Calculation of Heavy Metal Pollution Index (HPI)}

The HPI is a very useful tool in evaluating overall pollution of water bodies with respect to heavy metals. This method is based on weighted arithmetic quality [29] [30]. In this indexing, weights $\left(w_{i}\right)$ between 0 and 1 were assigned for each metal and the critical pollution index value is 100 [14] [31]. The rating is based on the relative importance individual quality considerations and defined as inversely proportional to the recommended standard $\left(S_{i}\right)$ for each parameter. The calculation of HPI involves the following steps. First, the calculation of weightage 
Table 3. The WQI categories [32].

\begin{tabular}{cc}
\hline Range & Quality \\
$<50$ & Excellent water \\
$50-100$ & Good water \\
$100-200$ & Poor water \\
$200-300$ & Very poor water \\
$>300$ & Unsuitable for drinking \\
\hline
\end{tabular}

$\left(W_{i}\right)$ of $i^{\text {th }}$ parameter using the formula above:

$$
W_{i}=k / S_{i}
$$

where $k$ is the proportionality constant and $S_{i}$ is the standard permissible value of $i^{\text {th }}$ parameter (adopted standard is the WHO limit 2011).

Second, the calculation of the quality $\left(Q_{i}\right)$ rating for each of the heavy metal.

$$
Q_{i}=100 \times V_{i} / S_{i}
$$

where, $Q_{i}$ is the sub index of $I^{\text {th }}$ parameter, $V_{i}$ is the monitored value of the $I^{\text {th }}$ parameter in $\mu \mathrm{g} / \mathrm{L}$ and $S_{i}$ the standard or permissible limit for the $i^{\text {th }}$ parameter [33].

After completion of the result, the concentration of each pollutant was converted into $H P I$.

$$
H P I=\frac{\sum_{i=1}^{n} W_{i} Q_{i}}{\sum_{i=1}^{n} W_{i}}
$$

\subsubsection{Calculation of Sodium Percentage and Sodium Adsorption Ratio (SAR)}

To understand the water quality for irrigation purposes, sodium adsorption ratio (SAR) and percent sodium ( $\mathrm{Na} \%$ ) are used with Wilcox and Riverside diagram. The $\% \mathrm{Na}$ is computed with respect to relative proportions of cations present in water, where the concentrations of ions are expressed in meq/l, using the following formula:

$$
\mathrm{Na} \%=\frac{\mathrm{Na}^{+}+\mathrm{K}^{+}}{\mathrm{Ca}^{2+}+\mathrm{Mg}^{2+}+\mathrm{K}^{+}} \times 100 \%
$$

The SAR is calculated from the ratio of sodium to calcium and magnesium, using the following formula:

$$
\mathrm{SAR}=\frac{\mathrm{Na}^{+}}{\frac{\sqrt{\mathrm{Ca}^{2+}+\mathrm{Mg}^{2+}}}{2}}
$$

There is a close relationship between SAR value in irrigation and the extent to which $\mathrm{Na}^{+}$is absorbed [34]. In fact, high concentration of dissolved ions in water can affect plants, physicochemical properties of soils and can lead to lower 
productivity and destruction of soil structure [34] [35].

\section{Results and Discussion}

\subsection{Physicochemical Characteristics}

The summary statistics of the physicochemical parameters in the study area are given in Table 4. The trends of seasonal variation are represented by Box plots in Figure 4. The pH values of Bétaré-Oya varied from 5.77 to 8.84 in the dry season and 5.42 to 7.58 during the wet seasons. These results show that water samples from rivers have acidic to basic properties. In general, high $\mathrm{pH}$ values were observed at the sampling sites $\mathrm{LOM}_{1}, \mathrm{LOM}_{3}$ and $\mathrm{MLB}_{5}$. These basic $\mathrm{pH}$ values could be linked to the high gold mining activities which is carried out in the upstream portion, which experiences oil spills or leakages from excavation machinery and transportation vehicles [36] [37]. Additionally, samples taken in the dry period have high $\mathrm{pH}$ values compared to the wet period (Figure 4(a)). This difference is due to a high concentration of chemical products used during exploitation which are often diffused during the rainy season. The basic to acidic $\mathrm{pH}$ in Bétaré-Oya are generally higher than those observed in the other forest areas of South Cameroon [38] [39]. They are of the same order like those in gold

Table 4. Statistical summary of physico-chemical parameters.

\begin{tabular}{|c|c|c|c|c|c|c|c|c|c|c|c|c|}
\hline \multirow[b]{2}{*}{ Parameters } & \multirow[b]{2}{*}{ Unit } & \multirow[b]{2}{*}{$\mathrm{N}$} & \multicolumn{5}{|c|}{ Wet period } & \multicolumn{5}{|c|}{ Dry period } \\
\hline & & & Min & $\operatorname{Max}$ & Mean & Med & Std & Min & $\operatorname{Max}$ & Mean & Med & Std \\
\hline $\mathrm{pH}$ & & 71 & 5.42 & 7.58 & 6.62 & 6.65 & 0.41 & 5.77 & 8.84 & 7.35 & 7.39 & 0.80 \\
\hline EC & $\mu \mathrm{Sm} / \mathrm{cm}$ & 71 & 11.60 & 122.10 & 37.37 & 27.40 & 23.98 & 12.50 & 62.90 & 26.32 & 21.40 & 15.48 \\
\hline Turb & NTH & 71 & 2.30 & 4758.00 & 228.16 & 64.30 & 669.18 & 1.22 & 276.00 & 82.76 & 53.35 & 88.67 \\
\hline Alc & $\mu \mathrm{eq} / \mathrm{L}$ & 71 & 29.00 & 733.00 & 205.63 & 148.51 & 168.10 & 357.10 & 927.80 & 648.91 & 693.55 & 197.17 \\
\hline TSS & $\mathrm{mg} / \mathrm{L}$ & 71 & 2.00 & 8996.00 & 307.05 & 60.33 & 1215.47 & 6.60 & 4886.00 & 480.45 & 66.20 & 1244.90 \\
\hline $\mathrm{Na}^{+}$ & $\mu e q / L$ & 71 & 13.86 & 310.27 & 65.87 & 47.11 & 53.77 & 31.13 & 216.09 & 77.76 & 53.70 & 52.68 \\
\hline $\mathrm{NH}_{4}^{+}$ & $\mu \mathrm{eq} / \mathrm{L}$ & 71 & $<\mathrm{DL}$ & 8.92 & 2.04 & 1.68 & 1.98 & $<\mathrm{DL}$ & 2.78 & 0.76 & 0.00 & 1.17 \\
\hline $\mathrm{K}^{+}$ & $\mu e q / L$ & 71 & 4.80 & 69.01 & 37.41 & 35.11 & 14.76 & 13.08 & 140.77 & 35.00 & 26.24 & 30.04 \\
\hline $\mathrm{Mg}^{2+}$ & $\mu e q / L$ & 71 & 2.49 & 301.44 & 71.58 & 45.71 & 76.94 & 16.67 & 254.17 & 57.04 & 39.90 & 55.75 \\
\hline $\mathrm{Ca}^{2+}$ & $\mu e q / L$ & 71 & 2.57 & 216.14 & 67.97 & 55.15 & 43.29 & 18.50 & 178.00 & 66.43 & 49.25 & 40.47 \\
\hline $\mathrm{TZ}^{+}$ & $\mu \mathrm{eq} / \mathrm{L}$ & 71 & 70.30 & 845.16 & 242.83 & 178.20 & 172.49 & 119.21 & 580.04 & 236.23 & 192.53 & 141.77 \\
\hline $\mathrm{F}^{-}$ & $\mu e q / L$ & 71 & 0.79 & 9.66 & 2.86 & 2.09 & 1.95 & 1.05 & 6.32 & 2.48 & 1.58 & 1.77 \\
\hline $\mathrm{Cl}^{-}$ & $\mu \mathrm{eq} / \mathrm{L}$ & 71 & 1.07 & 19.18 & 5.27 & 4.38 & 3.71 & 1.41 & 11.08 & 4.17 & 2.97 & 3.09 \\
\hline $\mathrm{NO}_{3}^{-}$ & $\mu \mathrm{eq} / \mathrm{L}$ & 71 & $<\mathrm{DL}$ & 276.59 & 14.78 & 8.19 & 36.81 & $<\mathrm{DL}$ & 40.32 & 3.88 & 0.46 & 9.95 \\
\hline $\mathbf{P O}_{4}^{3-}$ & $\mu e q / L$ & 71 & $<\mathrm{DL}$ & 4.48 & 0.56 & 0.00 & 1.01 & $<\mathrm{DL}$ & 4.05 & 1.07 & 0.57 & 1.33 \\
\hline $\mathrm{SO}_{4}^{2-}$ & $\mu \mathrm{eq} / \mathrm{L}$ & 71 & 0.13 & 87.40 & 13.67 & 6.61 & 17.89 & $<\mathrm{DL}$ & 90.74 & 12.55 & 5.74 & 22.57 \\
\hline $\mathrm{HCO}_{3}^{-}$ & $\mu \mathrm{eq} / \mathrm{L}$ & 71 & 29.02 & 733.00 & 205.80 & 148.51 & 168.03 & 357.38 & 927.87 & 648.87 & 693.44 & 197.09 \\
\hline $\mathrm{TZ}^{-}$ & $\mu \mathrm{eq} / \mathrm{L}$ & 71 & 36.71 & 859.19 & 240.08 & 174.18 & 182.97 & 371.94 & 971.09 & 670.54 & 740.39 & 202.05 \\
\hline
\end{tabular}

Min.: minimum, Max: maximum, Std: standard deviation, Med: median. 

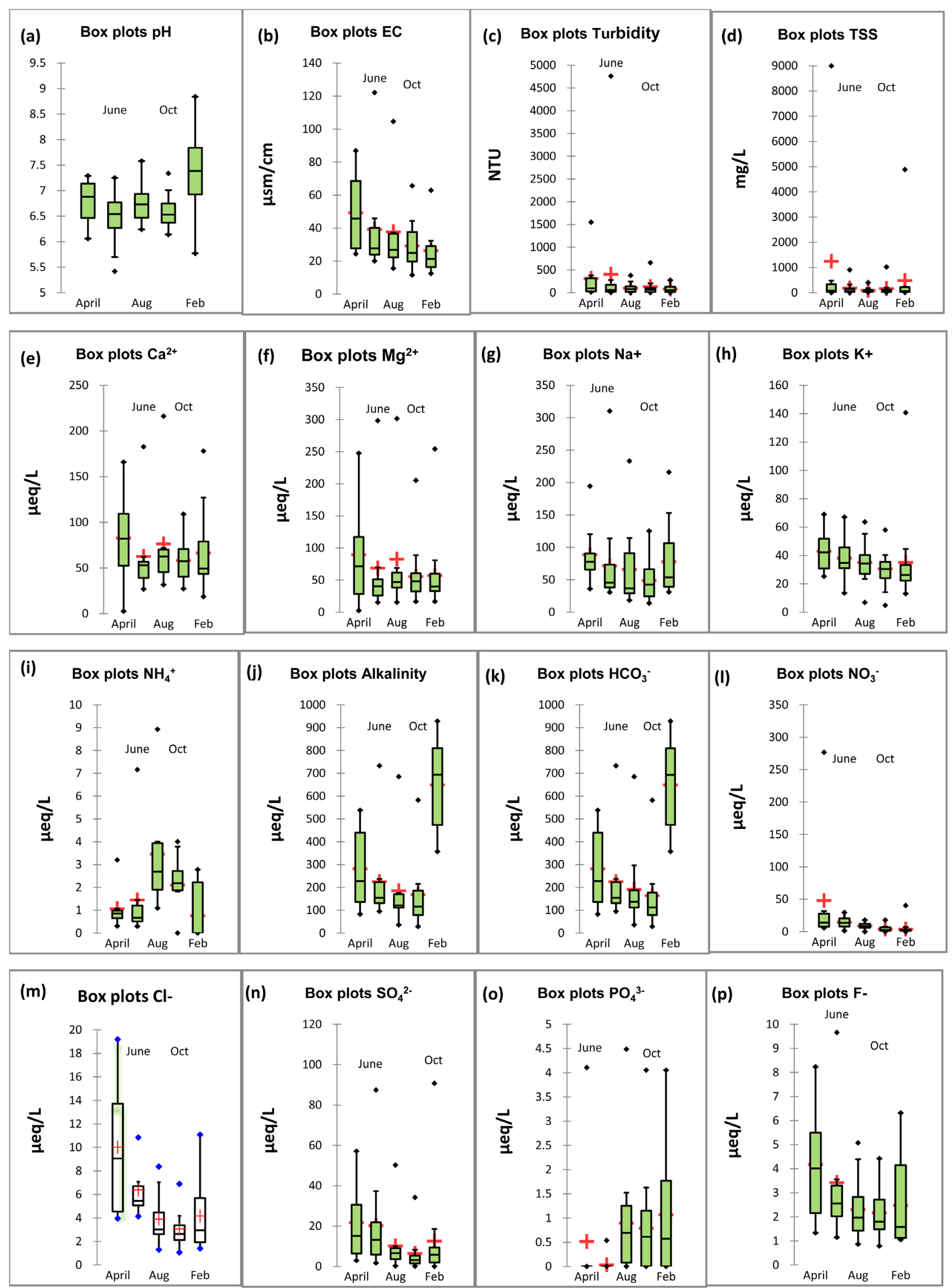

Figure 4. Trend of seasonal variation of water quality parameters in Bétaré-Oya. 
mining basins of Lower Pra in Ghana and in the South eastern part of Senegal [36] [37].

The EC values varied within a range of $12.50-62.90 \mu \mathrm{S} / \mathrm{cm}$ in dry period and $11.60-122.10 \mu \mathrm{S} / \mathrm{cm}$ in wet period. This type of water is very weakly to weakly mineralized [40] like most of the water in the forest part of South Cameroon flowing on the plutono-metamorphic basement [41] [42]. The maximum EC values were determined at $\mathrm{MLB}_{4}, \mathrm{MMR}_{4}, \mathrm{MLB}_{5}$ sites, during the wet period (Figure 4(b)), and appear to depend on increasing ion contents related to pollutants from extensive mining activity in the study area. It is also important to note that EC varies from one point to another. This spatial variation is due to the importance and the intensity of mining activities around each sampling point.

The turbidity and the TSS of the studied water varied respectively from 1.22 to 276.00 NTU and from 6.60 to $4886.00 \mathrm{mg} / \mathrm{L}$, in the dry period. During the wet season, these elements varied between 2.30 to $4758.00 \mathrm{NTU}$ and 2.00 to 8996.00 $\mathrm{mg} / \mathrm{L}$. The variation of TSS is sensibly proportional to that of turbidity [43]. The high turbidity and TSS mainly observed around mining sites, such as $\mathrm{MMR}_{4}$, $\mathrm{MMR}_{5}$ and $\mathrm{MLB}_{4}$ especially in wet period (Figure 4(c) and Figure 4(d)). Around these sample points, the river bed dug by excavators are washed and panned to extract gold. However, TSS and turbidity decreases in the Lom, particularly in $\mathrm{LOM}_{2}$ and $\mathrm{LOM}_{3}$ points, found in the mining zones. This decrease in turbidity and TSS in the Lom could be due to a high dilution. The TSS of thepresent study are higher than those obtained by [44] [45] in the Nyong, Ntem, Dja and Boumba respectively ( $6 \leq \mathrm{TSS} \leq 30 \mathrm{mg} / \mathrm{L}$ ), similar to values in forest zone of South Cameroon. The TSS and turbidity are equally higher than those of streams in the forest/savana contact zone such as the Sanaga and the Mbam ( $5 \leq$ TSS $\leq 82 \mathrm{mg} / \mathrm{L}$ and $6 \leq \mathrm{TSS} \leq 350 \mathrm{mg} / \mathrm{L}$ respectively) [5]. On the contrary, the high TSS and turbidity values are similar to those found in the mining sites of Amazonia, $318<$ TSS $<2468 \mathrm{mg} / \mathrm{L}$ and $424<$ Turb $<2874$ NTU [46]. It can therefore be said that these high TSS and turbidity values were presumably a result of the activities of gold miners in this zone alongside deforestation, digging of river beds, dumping of solid and liquid waste resulting from gold washing (panning) and the high soil leaching as well as the barren materials during the rainy season [47].

\subsection{Major Ions}

The seasonal distribution of physico-chemical parameters are presented in Table 4. Generally, the decreasing order of magnitude of cations in Bétaré-Oya were in the following order $\mathrm{Na}^{+}>\mathrm{Mg}^{2+}>\mathrm{Ca}^{2+}>\mathrm{K}^{+}>\mathrm{NH}_{4}^{+}$. Sodium was the dominant cation with concentrations up to $310.27 \mu \mathrm{eq} / \mathrm{L}$, several times higher than other major cations. The total cationic charge $\mathrm{TZ}^{+}$varied from 72.52 to $845.16 \mu \mathrm{eq} / \mathrm{L}$ for an arithmetic mean of $243.10 \pm 165.65 \mu \mathrm{eq} / \mathrm{L}$. Bicarbonates and nitrates were major anions with concentrations up to $927.87 \mu \mathrm{eq} / \mathrm{L}$ and $276.59 \mu \mathrm{eq} / \mathrm{L}$ respectively. The concentration of anions decreases in the order: $\mathrm{HCO}_{3}^{-}>\mathrm{NO}_{3}^{-}>$ $\mathrm{SO}_{4}^{2-}>\mathrm{Cl}^{-}>\mathrm{F}^{-}>\mathrm{PO}_{4}^{3-}$. The value of major equivalent anions $\left(\mathrm{TZ}^{-}\right)$varied 
between $37.65 \mu \mathrm{eq} / \mathrm{L}$ and $977.40 \mu \mathrm{eq} / \mathrm{L}$ with an average value of $339.86 \pm 260.47$ $\mu \mathrm{eq} / \mathrm{L}$.

When comparing the wet period analysis results with dry period, higher concentrations were measured in the wet period for all major ions except for $\mathrm{HCO}_{3}^{-}, \mathrm{K}^{+}$and $\mathrm{SO}_{4}^{2-}$ that showed high concentrations during the dry season than rainy season (Figure $4(\mathrm{k})$ and Figure $4(1)$ ). This phenomenon is related to materials issued from the atmosphere, vegetation or from an anthropogenic source as the case of nitrate ions during the raining season [48].

Charge balance error was calculated for all the samples. In general the charge balance errors less than $\pm 5 \%$ were accepted. According to the present study, $48 \%$ of samples have charge balances between 5 and $10 \%$. Meanwhile, $52 \%$ of samples have ion balance slightly higher than $10 \%$ with a cationic deficit. In these cases, the deviations are attributed to an anion excess caused by a suspended contaminated load from mining and neighbouring agricultural zones around the study area [49]. These results are different from those obtained in the southern Cameroon forest area by [41] [42] where anionic deficiencies are attributed to organic anions.

Two main water types have been revealed in the study area (Figure 5) using the Piper Trilinear diagram [50]. The $\mathrm{CaMg}-\mathrm{HCO}_{3}$ water type represents $66 \%$ and $\mathrm{NaK}-\mathrm{HCO}_{3}$ type represents $34 \%$. The predominance of these water types is indicative of the process of mineral dissolution particularly the silicate minerals. The predominance of $\mathrm{CaMg}-\mathrm{HCO}_{3}$ and $\mathrm{NaK}-\mathrm{HCO}_{3}$ is in accordance with those

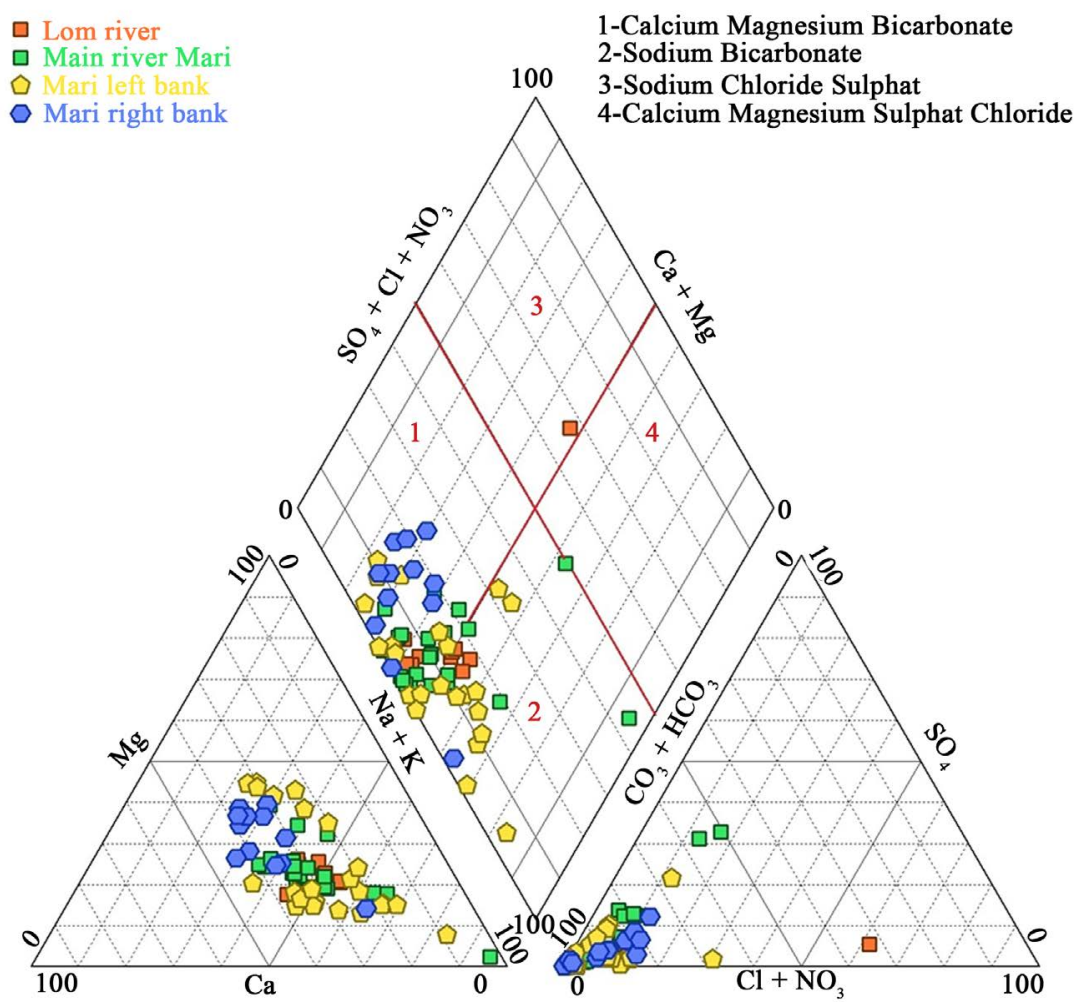

Figure 5. Piper diagram showing the chemical composition of surface water samples for this study from 2015-2016. 
of several authors who have worked in the same geological environments in Africa and in some parts of the world.

\subsection{Heavy Metals and $\mathrm{CN}^{-}$}

The concentration of the eight heavy metals ( $\mathrm{Pb}, \mathrm{Cd}, \mathrm{As}, \mathrm{Zn}, \mathrm{Cu}, \mathrm{Cr}, \mathrm{Mn}, \mathrm{Fe}$ ) and $\mathrm{CN}^{-}$in Betare-Oya gold mining area are shown in Table 5. The order of abundance was: $\mathrm{Fe}>\mathrm{Mn}>\mathrm{Pb}>\mathrm{Cr}>\mathrm{Cu}>\mathrm{Zn}>\mathrm{Cd}>\mathrm{As}>\mathrm{CN}$. Among them, only concentrations of $\mathrm{As}, \mathrm{Cu}, \mathrm{Zn}$ and $\mathrm{CN}^{-}$do not exceed WHO 2011 guidelines for water intended for human consumption. The metal concentrations were significantly different between sampling locations. The high concentration of heavy metals was along the streams where the separation mined minerals was carried out (gold washing pool).

Generally, the tailings from gold extraction are a major source of heavy metals in the water as well as chemical products used during the separation of gold and excavating machines (excavators and heavy duty trucks) [51] [52]. However, sometimes these elements can be derived from geological units, e.g. Cd exists in spharelite (ZnS) accompanied by Zn. Zinc also occurs in gold ore bodies in the form of sphalerite $(\mathrm{ZnS})$ which is often associated with galena. Arsenic from oxidation of sulfide minerals pyrite $\left(\mathrm{FeS}_{2}\right)$, arsenopyrite (FeAsS) in gold bearing rock [53].

Given the fact that their contents were above the WHO standards, of some elements, its origin can be influenced by anthropogenic activities such as mining. Metals such as $\mathrm{Mn}$. $\mathrm{Cd}, \mathrm{Cr}, \mathrm{Pb}$ are mostly leached from tailing waste, gold mine effluents or materials used during exploitation. $\mathrm{Pb}$ and $\mathrm{Cr}$ could be from exhaust pipes of heavy duty trucks, vehicles andmining machinery, Cd could be from the Ni-Cd batteries that are used in gold mining sites [49] [51]. Iron generally results from the leaching of ferrallitic soils with strong complexation with humic acids. This explains the high contents of Fe in surface water [38] [39]. $\mathrm{CN}^{-}$mainly originates from artisanal small-scale mining

Table 5. Metal level in surface water of Bétaré-Oya $(\mu / \mathrm{L})$ compared to WHO water guidelines (WHO 2011).

\begin{tabular}{cccccc}
\hline & $\mathrm{MRB}_{3}$ & $\mathrm{MMR}_{4}$ & $\mathrm{LOM}_{2}$ & $\mathrm{LOM}_{3}$ & WHO $(\mu \mathrm{g} / \mathrm{L})$ \\
\hline $\mathrm{Pb}$ & 100 & 100 & 100 & 100 & 10 \\
$\mathrm{Cd}$ & 50 & 50 & 50 & 50 & 3 \\
$\mathrm{As}$ & 10 & 10 & 10 & 10 & 10 \\
$\mathrm{Cu}$ & 800 & 100 & 100 & 100 & 2000 \\
$\mathrm{Zn}$ & 400 & 100 & 100 & 100 & 3000 \\
$\mathrm{Cr}$ & 20 & 100 & 20 & 100 & 50 \\
$\mathrm{Mn}$ & 100 & 700 & 100 & 700 & 400 \\
$\mathrm{Fe}$ & 570 & 850 & 2000 & 850 & 300 \\
$\mathrm{CN}$ & 10 & 10 & 10 & 10 & 70 \\
\hline
\end{tabular}


(semi-mechanized manner) from gold processing (cyanidation process) which consists of leaching gold from the ore as a gold-cyanide complex and recovering the gold by precipitation [54].

However, the solubility of these heavy metals is strongly governed by $\mathrm{pH}$ through precipitation of their oxides and hydroxides [55]. In the study area most of the $\mathrm{pH}$ values tend to neutral-alkaline which does not allow the phenomenon of acid mine drainage but rather contaminated neutral drainage. These phenomena may contribute to significant concentrations of metals in these samples [56].

\subsection{Processes Controlling Surface Water Chemistry}

To understand the mineralization process of the water in the Mari catchment, twomethods have been applied. These are Gibbs' model [57] and saturation indices (SI).

\subsubsection{Gibbs Model}

The data plotted on the Gibbs' diagram [57] in Figure 6 (TDS vs. $\mathrm{Na}^{+}+\mathrm{K} /\left(\mathrm{Na}^{+}\right.$ $+\mathrm{K}+\mathrm{Ca}^{2+}$ ) and $\mathrm{TDS}$ vs. $\mathrm{Cl} / \mathrm{Cl}+\mathrm{HCO}_{3}^{-}$) suggests that chemical weathering of rocks is the major mechanism controlling the hydrochemistry in the area. The lithology consists of mostly schist, quartzite, granites, and gneisses, $\mathrm{Na}$ and $\mathrm{K}$ are mainly derived from silicate rock weathering [58]. Rainwater also can contribute little amounts of $\mathrm{Na}$ to surface waters. The bicarbonate was the most abundant in the river water, despite the absence of a dominant carbonate lithology in the study area. The $\mathrm{HCO}_{3}{ }^{-}$could be derived from weathering of silicates rocks and $\mathrm{CO}_{2}$ from soil and organic material [58] [59]. In this study, alkalinity is mainly in the form of bicarbonates. Similar results have been obtained in the southern part of Cameroon by [38] [39].

\subsubsection{Saturation Indices (SI)}

Saturation indices (SI) are used to investigate the different forms of mineral phases such as precipitated, dissolved and adsorbed phases. The result summarized in Table 6 showed that all the water in the Mari and Lom Rivers were undersaturated with respect to carbonate minerals (aragonite, calcite, and dolomite), sulfate minerals (gypsum and anhydrite), $\mathrm{CO}_{2}, \mathrm{H}_{2} \mathrm{O}$ and $\mathrm{O}_{2}$, during all the study period This indicating the tendency of waters to dissolve more of these mineral phases and/or suggesting that these mineral phases are less abundant in the corresponding host rock [58] [59]. However, according to [60], the IS value in the Tawa River Central India situated in the humid tropical zone varied from negative in the monsoon, to positive values in the pre-monsoon season. They concluded that during the non-monsoon, calcite precipitation occurs and is washed off during the monsoon season. These results show that the saturation indices are a function of climate and lithology.

\subsection{Water Quality Index (WQI)}

To assess water quality of the river, $\mathrm{pH}, \mathrm{EC}$, Turbidity, TSS, $\mathrm{HCO}_{3}^{-}, \mathrm{Cl}^{-}, \mathrm{SO}_{4}^{2-}$, 


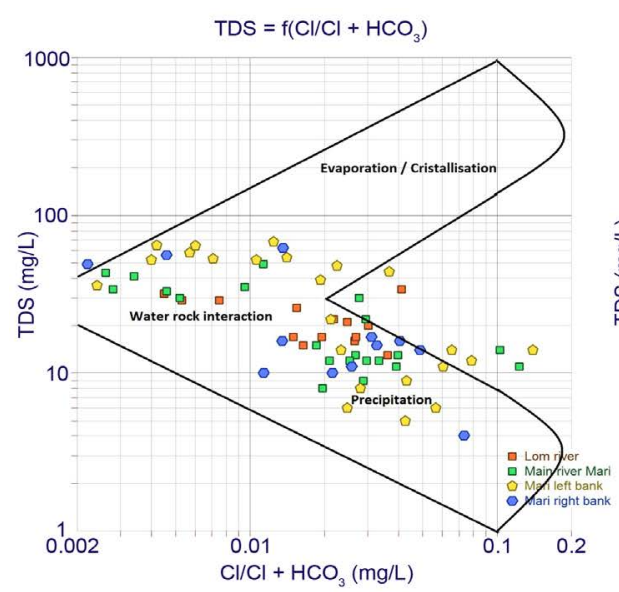

(a)

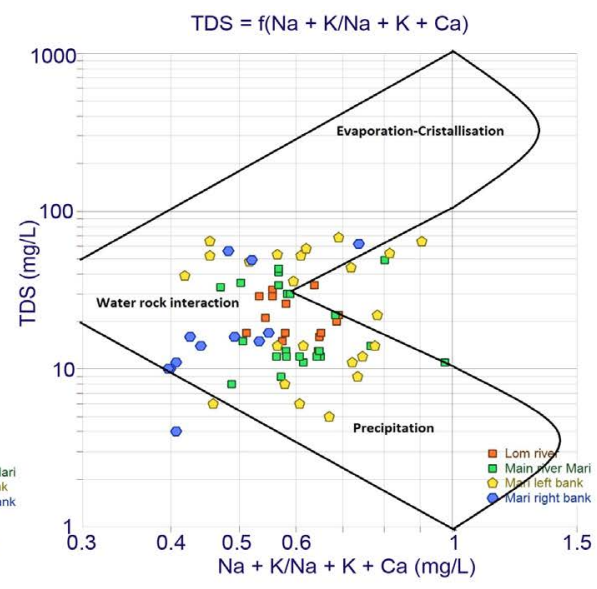

(b)

Figure 6. Major natural processes controlling water chemistry in the study area Adapted from Gibbs (1970).

Table 6. Summary of saturation indices (SI) obtained from geochemical calculations with DIAGRAMME software.

\begin{tabular}{|c|c|c|c|c|c|c|c|c|c|c|c|}
\hline Sampling point & Mineral phase & Anhydrite & Aragonite & Calcite & Dolomite & Gypsum & $\mathrm{H}_{2}(\mathrm{~g})$ & $\mathrm{H}_{2} \mathrm{O}(\mathrm{g})$ & $\mathrm{O}_{2}(\mathrm{~g})$ & Halite & $\mathrm{CO}_{2}(\mathrm{~g})$ \\
\hline \multirow{4}{*}{ LOM1-LOM3 } & Min & -5.94 & -3.83 & -3.69 & -7.32 & -5.72 & -25.68 & -1.51 & -41.6 & -11.55 & -4.52 \\
\hline & $\operatorname{Max}$ & -5.09 & -1.04 & -0.9 & -1.79 & -4.87 & -20.76 & -1.51 & -31.76 & -10.91 & -2.31 \\
\hline & Mean & -5.53 & -3.11 & -2.97 & -5.92 & -5.31 & -22.05 & -1.51 & -39.02 & -11.16 & -2.89 \\
\hline & Std & 0.21 & 0.81 & 0.81 & 1.61 & 0.21 & 1.25 & 0.00 & 2.51 & 0.21 & 0.56 \\
\hline \multirow{4}{*}{ MMR1-MMR5 } & Min & -6.64 & -5.56 & -5.41 & -10.71 & -6.42 & -23.16 & -1.51 & -44.32 & -12.03 & -3.53 \\
\hline & $\operatorname{Max}$ & -4.59 & -2.27 & -2.13 & -4.02 & -4.37 & -19.40 & -1.51 & -36.80 & -10.66 & -1.72 \\
\hline & Mean & -5.80 & -3.72 & -3.58 & -7.13 & -5.58 & -21.32 & -1.51 & -40.47 & -11.38 & -2.55 \\
\hline & Std & 0.59 & 0.79 & 0.79 & 1.64 & 0.59 & 1.02 & 0.00 & 2.04 & 0.39 & 0.58 \\
\hline \multirow{4}{*}{ MLB1-MLB5 } & Min & -7.57 & -5.02 & -4.87 & -9.93 & -7.35 & -25.06 & -1.51 & -42.92 & -12.13 & -4.70 \\
\hline & Max & -4.22 & -1.83 & -1.69 & -3.11 & -4.00 & -20.10 & -1.51 & -33.00 & -10.03 & -1.67 \\
\hline & Mean & -5.89 & -3.35 & -3.21 & -6.37 & -5.67 & -21.60 & -1.51 & -39.93 & -11.03 & -2.59 \\
\hline & Std & 1.02 & 0.99 & 0.99 & 2.11 & 1.02 & 1.16 & 0.00 & 2.33 & 0.55 & 0.62 \\
\hline \multirow{4}{*}{ MRB1-MRB3 } & Min & -6.51 & -5.62 & -5.48 & -10.89 & -6.29 & -23.68 & -1.51 & -45.44 & -12.22 & -3.39 \\
\hline & Max & -5.18 & -1.54 & -1.40 & -2.86 & -4.96 & -18.84 & -1.51 & -35.76 & -10.24 & -0.74 \\
\hline & Mean & -5.75 & -3.62 & -3.48 & -6.89 & -5.53 & -21.36 & -1.51 & -40.40 & -11.53 & -2.59 \\
\hline & Std & 0.40 & 0.96 & 0.96 & 1.88 & 0.40 & 1.41 & 0.00 & 2.83 & 0.52 & 0.82 \\
\hline
\end{tabular}

Min: minimuim; Max: maximuim; Std: standard deviation.

$\mathrm{Na}^{+}, \mathrm{Ca}^{2+}, \mathrm{Mg}^{2+}, \mathrm{NO}_{3}^{-}, \mathrm{F}^{-}$were taken into account for calculations of Water Quality Index (WQI) (Table 7). Furthermore, the World Health Organization (WHO, 2011) limits were used as standard. The computed values of WQI for the 71 water samples are between 12.589 and 5137.40; the water quality varied from "excellent" to "unsuitable for drinking". $34 \%$ of samples represent excellent water; $17 \%$ represents good water; $21 \%$ is poor water; $11 \%$ and $17 \%$ respectively for the very poor and unsuitable water for drinking. Highest WQI values were rec- 
orded at site $\mathrm{MMR}_{3} ; \mathrm{MMR}_{4} ; \mathrm{MMR}_{5} ; \mathrm{MLB}_{5} ; \mathrm{LOM}_{2}$ where an extensive mining activity is carried out. The spatial variations of WQI (Figure 7) suggested significant decrease of the water quality from upstream to downstream along the Mari and Lom rivers during the study period. The WQI value for each group of samples (Lom and Mari) shows that the sites in the Lom River (Figure 8(a)) and the main Mari River (Figure 8(b)) were the two most polluted sites in Bétaré-Oya. These results suggest that water quality in all of the above sites is controlled mainly by TSS and turbidity.

The water quality of the left tributary of Mari (Figure 8(d)) appear more deteriorated in relation to the right bank which has $66 \%$ of "excellent water" (Figure $8(\mathrm{c})$ ). This zone is not affected by mining activities (deforestation, digging of river beds, dumping of solid and liquid waste resulting from gold washing). Similar results were obtained by [16] in the Nile river in Egypt. According to this author, the water quality goes from good in the upstream to unsuitable for drinking in the down-stream, reflecting the impact of industrial activity domination on the deterioration of Nile water quality.

\subsection{Heavy Metal Pollution Index (HPI)}

For the HPI, the weightage (Wi) for all the four sampling points are presented in Table 8 and Table 9. The overall heavy metal pollution index of the Mari and

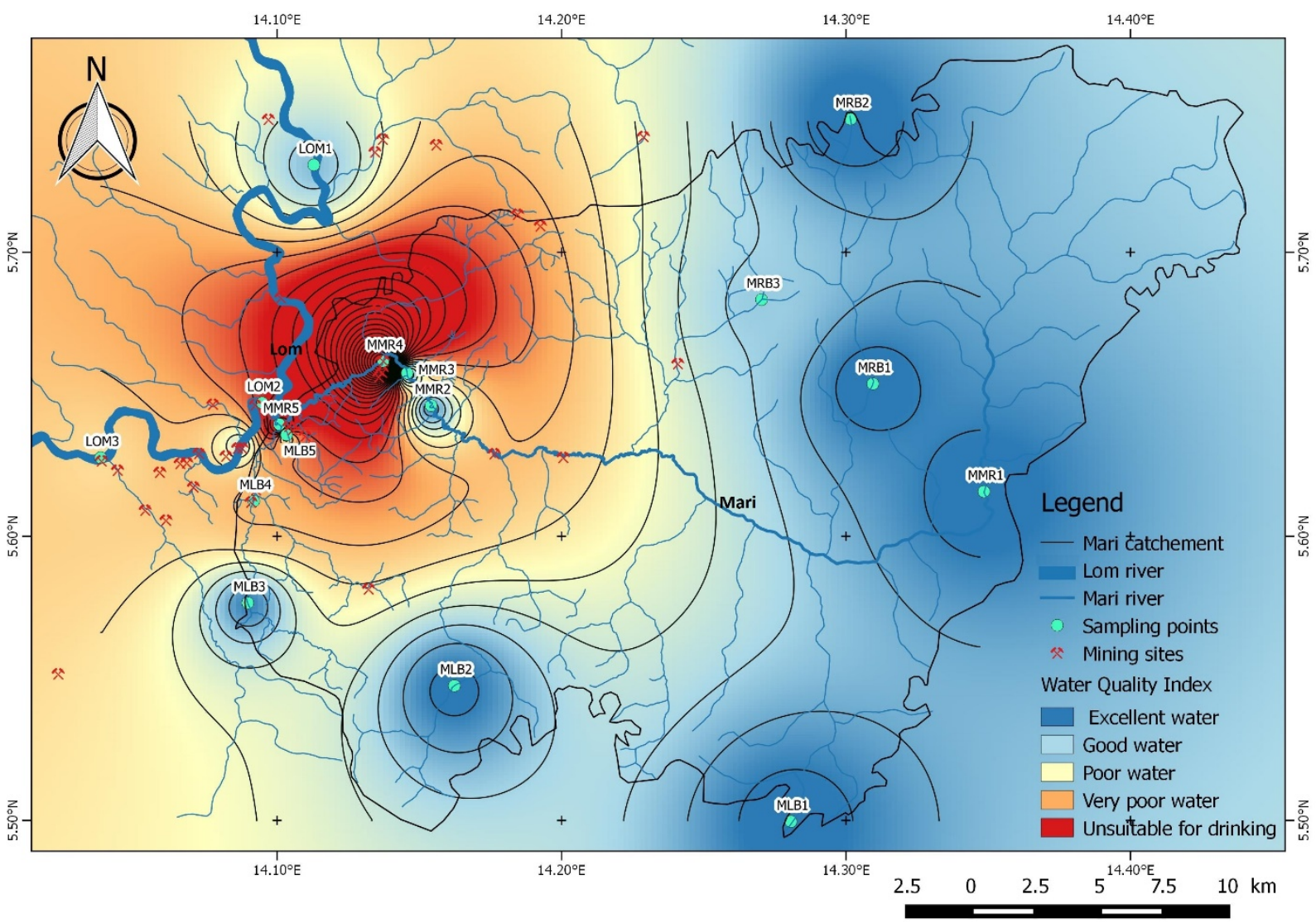

Figure 7. Spatial distribution of the water quality index (WQI) in Bétaré-Oya gold mining area. 
Table 7. Statistic values of WQI in Bétaré-Oya gold mining area.

\begin{tabular}{ccccccc}
\hline Site description & Sampling point & Min & Max & Mean & Med & VC \\
\hline River Lom & $\mathrm{LOM}_{1}-\mathrm{LOM}_{3}$ & 70.22 & 471.28 & 214.33 & 178.80 & 53.22 \\
Mari main river & $\mathrm{MMR1}^{-\mathrm{MMR}_{5}}$ & 21.48 & 5137.40 & 527.70 & 88.39 & 226.48 \\
River Mari right bank & $\mathrm{MRB}_{1}-\mathrm{MRB}_{3}$ & 12.59 & 253.53 & 62.14 & 29.90 & 113.77 \\
River Mari left bank & $\mathrm{MLB}_{1}-\mathrm{MLB}_{5}$ & 16.80 & 804.54 & 152.33 & 63.88 & 136.68 \\
\hline
\end{tabular}

Min: minimuim; Max: maximuim; VC: variation coefficient.
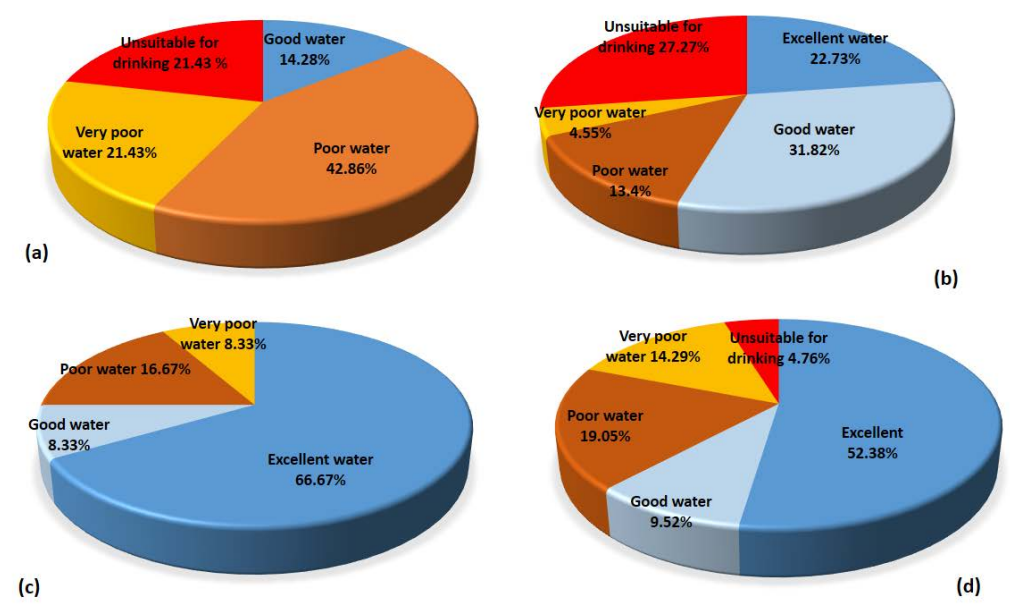

Figure 8. Graphical data representation of WQI in Bétaré-Oya gold mining area (a): Lom River; (b): Mari Main River; (c): Mari right bank; (d): Mari left bank.

Lom rivers was found to be 1195 on average, greater than the critical pollution index value of 100 , above which the overall pollution level should be considered unacceptable. At all sampling points, HPI calculated is far above the critical index limit of 100 (Table 8). This indicates that the water is critically polluted with respect to heavy metals. Similar results were obtained by [31] in India; and [61] in Nigeria.

Fe has the highest concentration in the Mari catchment and Lom River. Nevertheless, the weightage (Wi) given to Fe is very small. Therefore, in evaluation of HPI, this parameter does not contribute much on HPI value. However, heavy metals like $\mathrm{Pb}, \mathrm{Cd}, \mathrm{As}$, and $\mathrm{Cr}$ have been given no relaxation in drinking water standard and have been given high weightage (Wi) value in HPI calculation by [31]. Hence, even their smaller concentration in water samples makes the water of poor quality and gives high values of HPI [33]. The presence of these undesirable elements constitutes a potential danger to human health, to the aquatic biodiversity of this area and even to the water supply project for the town of Yaounde, from the river Sanaga.

\subsection{Water Quality for Irrigation Purposes}

According to the percentage of sodium and electrical conductivity (Figure 9(a)), all samples are suitable (excellent) for irrigation. The SAR data plotted on the US 
Salinity Diagram (Figure 9(b)) showed that $99 \%$ of the samples were categorized in low, class indicating low sodium and low to moderate salinity water, which can be used safely for irrigation purposes in almost all types of soils [62].

However, the presence of some metallic elements in low contents in the surface water of Bétaré-Oya can be phytotoxic or could become phytotoxic when their concentrations eventually become higher [63].

\section{Conclusion}

The present study assesses the surface water quality in the Bétaré-Oya gold min

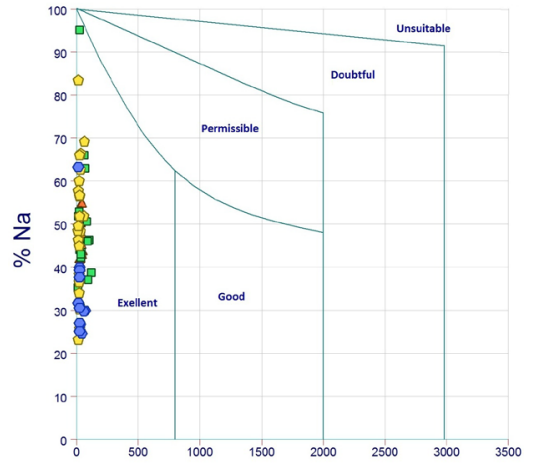

Electrical conductivity $\mu \mathrm{S} / \mathrm{cm}$

(a)

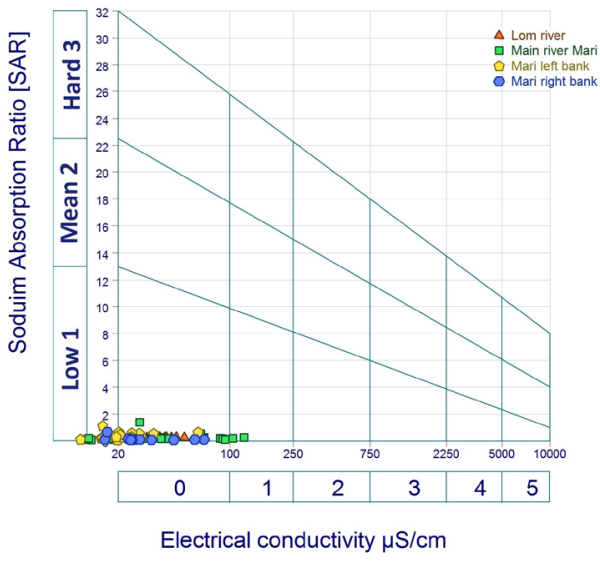

(b)

Figure 9. Classification of irrigation waters (a) Wilcox, after Wilcox 1948; (b) Riverside, after US Salinity Laboratory Staff 1954.

Table 8. Relative weight of heavy metal pollution in Bétaré-Oya gold mining area.

\begin{tabular}{cccc}
\hline Heavy metals & wi (k) & Unit weightage (Wi) & Standard permissible value (Si) \\
\hline $\mathrm{Pb}$ & 1 & 0.1 & 10 \\
$\mathrm{Cd}$ & 1 & 0.33 & 3 \\
$\mathrm{As}$ & 1 & 0.1 & 10 \\
$\mathrm{Cu}$ & 1 & 0.0005 & 2000 \\
$\mathrm{Zn}$ & 1 & 0.0003 & 3000 \\
$\mathrm{Cr}$ & 1 & 0.02 & 50 \\
$\mathrm{Mn}$ & 1 & 0.0025 & 400 \\
$\mathrm{Fe}$ & 1 & 0.0033 & 300 \\
& $\Sigma 8$ & $\Sigma 0.56$ & \\
\hline
\end{tabular}

Table 9. HPI values in Bétaré-Oya gold mining area.

\begin{tabular}{cccc}
\hline Sampling site & Wi & Wi $\times$ Qi & HPI \\
\hline MRB $_{3}$ & 0.56 & 667.08 & 1191.21 \\
MMR $_{4}$ & 0.56 & 670.94 & 1198.11 \\
OOM $_{2}$ & 0.56 & 668.64 & 1194.01 \\
LOM $_{3}$ & 0.56 & 670.94 & 1198.11 \\
\hline
\end{tabular}


ing area in East-Cameroon. Based on physicochemical characteristics the water is acidic to basic $(5.42<\mathrm{pH}<8.84)$ and very weakly to weakly mineralized. Two water types were identified: $\mathrm{CaMg}-\mathrm{HCO}_{3}(66 \%)$ and $\mathrm{NaK}-\mathrm{HCO}_{3}(34 \%)$. All the water is undersaturated with regard to carbonate and sulphate minerals indicating the tendency of water to dissolve more of these mineral phases and/or suggesting that these mineral phases are less abundant in the corresponding host rock. According to the water quality, the computed WQI values are between 12.59 and 5137.40, thus ranging from excellent to unsuitable water quality for drinking. The main pollutant sources are gold mining activities (excavating, deforestation, digging of river beds, dumping of solid and liquid waste resulting from gold washing, high soil leaching as well as the barren materials during rainy season) and agriculture. The effects of water quality parameters on the WQI map show that the highest value belongs to the TSS and Turbidity parameters compared with the other parameters. The overall HPI calculated based on the concentration of heavy metal showed that the water samples from the Mari and Lom rivers are critically contaminated with respect to heavy metals (HPI value is far above the critical index limit of 100). Based on the classification of irrigation water according to SAR and \% $\mathrm{Na}$ values, all the sample locations are suitable for irrigation purposes. However, attention must be paid to the presence of some metallic elements in low contents in the surface water of Bétaré-Oya. These results provide a baseline reference on the future monitoring of the Sanaga basin and its tributaries such as Mari, Mbal, Nakoyo and Lom rivers. It is also suggested that strategies of water pollution prevention should be implemented continuously for proper management in the mining areas around East Cameroon particularly in the Betare Oya zone.

\section{Acknowledgements}

This write up constitutes part of data generated during the Ph.D study of the corresponding author, in the University of Yaoundé I (Cameroon) in collaboration with the University of Antananarivo (Madagascar) and was supported by AFIMEGQ project “Africa For Innovation, Mobility, Exchange, Globalization and Quality" grant No. AF13FD0038. The authors also thank: Professor Mbacham Wilfred of the University of Yaoundé I for his support, the Geosciences Laboratory of Superficial Formations and Applications, Faculty of Science, University of Yaoundé I and the Laboratory of Geochemical Analysis of Water (LAGE) of the Institute of Geological and Mining Research (IRGM), Nkolbisson, Cameroon where analyses were carried out.

\section{References}

[1] MINEE, GWP-Cmr (2009) Etat des Lieux du Secteur de L'eau au Cameroun: Eau et Environnement (Tome 1). Technical Report, Yaoundé, 235.

[2] MINEE, GWP-Cmr (2009) Etat des Lieux du Secteur de L'eau au Cameroun: Connaissances et Usages de Ressources en Eau (Tome 2). Technical Report, Yaoundé, 184.

[3] Fantong, W.Y., Kamtchueng, B.T., Ketchemen-Tandia, B., Kuitcha, D., Ndjama, J., 
Fouepe, A.T., Takem, G.E.I., Wirmvem, M.J., Djomou, B.S.L., Ako, A.A., Nkeng, G.E., Kusakabe, M. and Ohba, T. (2016) Variation of Hydrogeochemical Characteristics of Water in Surface Flows, Shallow Wells, and Boreholes in the Coastal City of Douala (Cameroon). Hydrological Sciences Journal, 61, 2916-2929. https://doi.org/10.1080/02626667.2016.1173789

[4] Liénou, G. (2007) Impact Anthropiques et Climatiques sur L'Evolution Recente de Quelques Bassins Versant Representatifs au Cameroun: Climatologie, Hydrologie, Erosion, Transport des Matieres. Ph.D. Thesis, Université de Yaoundé I, Yaoundé.

[5] Ngoupayou, N.J.R., Dzana, J.G., Kpoumie, A., Ghogomu, T.R., Takounjou, F.A., Braun, J.J. and Ekodeck, G.E. (2016) Present-Day Sediment Dynamics of the Sanaga Catchment (Cameroon): From the Total Suspended Sediment (TSS) to Erosion Balance. Hydrological Sciences Journal, 61, 1080-1093.

https://doi.org/10.1080/02626667.2014.968572

[6] Bakia, M. (2014) East Cameroon's Artisanal and Small-Scale Mining Bonanza: How Long Will It Last? The Futures of Small-Scale Mining in Sub-Saharan Africa. Futures, 62, 40-50. https://doi.org/10.1016/j.futures.2013.10.022

[7] Centre d'Appui et de Promotion des Activités Minières (CAPAM) (2016) Mission de suivi environnemental des sites d'exploitations minières artisanales dans les régions de l'Est et de l'Adamaoua $44 \mathrm{p}$.

[8] Fon, A.F., Bih, V.C. and Cheo, E.S. (2012) Application of Electrical Resistivity and Chargeability Data on a GIS Platform in Delineating Auriferous Structures in a Deeply Weathered Lateritic Terrain, Eastern Cameroon. International Journal of Geosciences, 2, 960-971. https://doi.org/10.4236/ijg.2012.325097

[9] Tehna, N., Nguene, F.D., Etame, J., Ekodo, M.J.M., Tang, N.S., Suh, E.C. and Bilong, P. (2015) Impending Pollution of Betare Oya Opencast Mining Environment (Eastern Cameroon). Journal of Environmental Science and Engineering B, 4, 37-46.

[10] Vishiti, A., Suh, C.E., Lehmann, B., Egbe, J.A. and Shemang, E.M. (2015) Gold Grade Variation and Particle Microchemistry in Exploration Pits of the Batouri Gold District, SE Cameroon. Journal of African Earth Sciences, 111, 1-13. https://doi.org/10.1016/j.jafrearsci.2015.07.010

[11] Ramakrishnaiah, C.R., Sadashivaiah, C. and Ranganna, G. (2009) Assessment of Water Quality Index for the Ground-Water in Tumkur Taluk, Karnataka State, India. E-Journal of Chemistry, 6, 523-530. https://doi.org/10.1155/2009/757424

[12] Al-Mashagbah, A.F. (2015) Assessment of Surface Water Quality of King Abdullah Canal, Using Phy-Sico-Chemical Characteristics and Water Quality Index, Jordan. Journal of Water Resource and Protection, 7, 339-352. https://doi.org/10.4236/jwarp.2015.74027

[13] Abdel-Satar, A.M., Ali, M.H. and Goher, M.E. (2017) Indices of Water Quality and Metal Pollution of Nile River. Egypt Egyptian Journal of Aquatic Research, 43, 2129. https://doi.org/10.1016/j.ejar.2016.12.006

[14] Reza, R. and Singh, G. (2010) Heavy Metal Contamination and Its Indexing Approach for River Water. International Journal of Environmental Sciences Technology, 7, 785-792. https://doi.org/10.1007/BF03326187

[15] Ngako, V., Affaton, P., Nnange, J.M. and Njanko, T. (2003) Pan-African Tectonic Evolution in Central and Southern Cameroon: Transpression and Transtension during Sinistral Shear Movements. Journal of African Earth Sciences, 36, 207-214. https://doi.org/10.1016/S0899-5362(03)00023-X

[16] Kankeu, B. (2008) Anisotropie de la Susceptibilite Magnetique (ASM) et Fabriques 
des Roches Neoproterozoiques des Regions de Garga-Sarali et Betare-Oya a L'Est de Cameroun: Implications Geodynamiques pour L'Evolution de la Chaine PanAfricaine de L'Afrique Centrale. Ph.D. Thesis, University of Yaoundé I, Yaoundé.

[17] Kankeu, B., Greiling, R.O. and Nzenti, J.P. (2009) Pan-African Strike-Slip Tectonics in Eastern Cameroon-Magnetic Fabrics (AMS) and Structure in the Lom Basin and Its Gneissic Basement. Precambrian Research, 174, 258-272.

https://doi.org/10.1016/j.precamres.2009.08.001

[18] Soba, D. (1989) La Serie de Lom: Etude Geologique et Geochronologique D'un Bassin Volcano-Sedimentaire de la Chaine Panafricaine a L'Est de Cameroun. Ph.D. Thesis, University of Pierre and Marie Curie, Paris.

[19] Toteu, S.F., Penaye, J., Deloule, E., Van Schmus, W.R. and Tchameni, R. (2006) Diachronous Evolution of Volcano-Sedimentary Basins North of the Congo Craton: Insights from U-Pb Ion Microprobe Dating of Zircons from the Poli, Lom and Yaounde' Groups (Cameroon). Journal of African Earth Sciences, 44, 428-442. https://doi.org/10.1016/j.jafrearsci.2005.11.011

[20] Freyssinet, P., Lecomte, P. and Edimo, A. (1989) Dispersion of Gold and Base Metals in the Mborguéné Lateritic Profile, East Cameroun. Journal of Geochemical EXploration, 32, 99-116. https://doi.org/10.1016/0375-6742(89)90050-2

[21] Toteu, S.F., Van, S.W.R., Penaye, J. and Michard, A. (2001) New U-Pb and Sm-Nd Data from North-Central Cameroon and Its Bearing on the Pre-Pan African History of Central Africa. Precambrian Research, 108, 45-73. https://doi.org/10.1016/S0301-9268(00)00149-2

[22] Segalen, P. (1967) Les Sols et la Geomorphologie du Cameroun. Cahier ORSTOM Series Pédologique, 2,137-187.

[23] Nollet, L.M.L. (2007) Hand Book of Water Analysis. 2nd Edition, Taylor \& Francis Group, London.

[24] Rodier, J. (2009) L'analyse de L'eau Naturelle, Eaux Résiduaires, Eau de Mer. 9th Edition, Dunod, Paris.

[25] Horton, R.K. (1965) An Index-Number System for Rating Water Quality. Journal of Water Pollution, 37, 300-306.

[26] Aenab, A.M., Singh, S.K. and Al-Rubaye, A.A.M. (2012) Evaluation of Tigris River by Water Quality Index Analysis Using C++ Program. Journal of Water Resource and Protection, 4, 523-527. https://doi.org/10.4236/jwarp.2012.47061

[27] Ewaid, S.H. and Abed, S.A. (2017) Water Quality Index for Al-Gharraf River, Southern Iraq. Egyptian Journal of Aquatic Research.

https://doi.org/10.1016/j.ejar.2017.03.001

[28] World Health Organization (2011) Guidelines for Drinking-Water Quality. Recommandations. 4th Edition, World Health Organization, Geneva.

[29] Prasad, B. and Sangita, K. (2008) Heavy Metal Pollution Index of Ground Water of an Abandoned Open Cast Mine Filled with Fly Ash: a Case Study. Mine Water and the Environment, 27, 265. https://doi.org/10.1007/s10230-008-0050-8

[30] Singh, G. and Rakesh, K.K. (2016) Heavy Metal Contamination and Its Indexing Approach for Groundwater of Goa Mining Region, India. Applied Water Sciences, 7, 1479-1485. https://doi.org/10.1007/s13201-016-0430-3

[31] Bhardwaj, R., Gupta, A. and Garg, J.K. (2017) Evaluation of Heavy Metal Contamination Using Environmetrics and Indexing Approach for River Yamuna, Delhi Stretch, India. Water Sciences, 31, 52-66. https://doi.org/10.1016/j.wsj.2017.02.002 
[32] Batabyal, A.K. and Chakraborty, S. (2015) Hydrogeochemistry and Water Quality Index in the Assessment of Groundwater Quality for Drinking Uses. Water Environment Research, 87, 7. https://doi.org/10.2175/106143015X14212658613956

[33] Mohan, S.V., Nithila, P. and Reddy, S.J. (1996) Estimation of Heavy Metal in Drinking Water and Development of Heavy Metal Pollution Index. Journal of Environmental Science and Health, A-31, 283-289. https://doi.org/10.1080/10934529609376357

[34] Wilcox, L.V. (1948) Classification and Use of Irrigation Waters. U.S. Department of Agriculture, Washington DC, 962.

[35] US Salinity Laboratory Staff (1954) Diagnosis and Improvement of Saline and Alkali Soils. Agricultural Handbook No. 60. United States Department Of Agriculture, Washington DC, 160.

[36] Ahialey, E.K., Serfoh-Armah, Y. and Kortatsi, B.K. (2010) Hydrochemical Analysis of Groundwater in the Lower Pra Basin of Ghana. Journal of Water Resource and Protection, 2, 864-871. https://doi.org/10.4236/jwarp.2010.210103

[37] Ibrahima, M., Moctar, D., Maguette, D.N., Diakher, M.H., Malick, N.P. and Serigne, F. (2015) Evaluation of Water Resources Quality in Sabodala Gold Mining Region and Its Surrounding Area (Senegal). Journal of Water Resource and Protection, 7, 247-263. https://doi.org/10.4236/jwarp.2015.73020

[38] Viers, J., Dupre, B., Braun, J.J., Deberdt, S., Angeletti, B., Ngoupayou, N.J.R. and Michard, A. (2000) Major and Trace Element Abundances, and Strontium Isotopes in the Nyong Basin Rivers Cameroon Constraints on Chemical Weathering Processes and Elements Transport Mechanisms in Humid Tropical Environments. Chemical Geology, 169, 211-241. https://doi.org/10.1016/S0009-2541(00)00298-9

[39] Braun, J.J., Marechal, J.C., Riotte, J., Boeglin, J.L. and Bedimo, B.J.P. (2012) Elemental Weathering Fluxes and Saprolite Production Rate in a Central African Lateritic Terrain (Nsimi, South Cameroon). Geochimica et Cosmochimica, 99, 243-270. https://doi.org/10.1016/j.gca.2012.09.024

[40] Detay, M. (1993) Le Forage D’eau, Réalisation, Entretien, Réhabilitation. Masson, Paris, 375 .

[41] Boeglin, J.L., Ndam, J.R. and Braun, J.J. (2003) Composition of the Different Reservoir Waters in a Tropical Humid Area: Example of the Nsimi Catchment (Southern Cameroon). Journal of African Earth Sciences, 37, 103-110. https://doi.org/10.1016/S0899-5362(03)00041-1

[42] Braun, J.J., Ngoupayou, N.J.R., Viers, J., Dupre, B., Bedimo, B.J.P., Boeglin, J.L., Robain, H., Nyeck, B., Freydier, R., Nkamdjou, S.L., Rouiller, J. and Muller, J.P. (2005) Present Weathering Rates in a Humid Tropical Watershed: Nsimi Site (South Cameroon). Geochimica et Cosmochimica Acta, 69, 357-387. https://doi.org/10.1016/j.gca.2004.06.022

[43] Rügner, H., Schwientek, M., Beckingham, B., Kuch, B. and Grathwohl, P. (2013) Turbidity as a Proxy for Total Suspended Solids (TSS) and Particle Facilitated Pollutant Transport in Catchments. Environmental Earth Sciences, 69, 373-380. https://doi.org/10.1007/s12665-013-2307-1

[44] Sigha, L. (1994) Fonctionnement Hydrochimique D’un Ecosysteme Forestier de L'Afrique Centrale: La Ngoko a Mouloundou (Sud-Est du Cameroun). Ph.D. Thesis, Université Paris XI Orsay, Paris.

[45] Olivry, J.C. (1977) Transports Solides en Suspension au Cameroun. In: Erosion and Solid Matter Transport in Inland Water, Paris, International Association of Hydrological Sciences Publisher, Potsdam, 134-141. 
[46] Mol, J.H. and Ouboter, P.E. (2004) Downstream Effects of Erosion from Small-Scale Gold. Conservation Biology, 18, 201-214. https://doi.org/10.1111/j.1523-1739.2004.00080.x

[47] Betancourt, O., Narvaez, A. and Roulet, M. (2005) Southern Ecuador: A Study of Environmental Impacts and Human Exposures. EcoHealth, 2, 323-332. https://doi.org/10.1007/s10393-005-8462-4

[48] Woocay, A. and Walton, J. (2008) Multivariate Analyses of Water Chemistry: Surface and Ground Water Interactions. Ground Water, 3, 437-449. https://doi.org/10.1111/j.1745-6584.2007.00404.x

[49] Aranguren, S.M.M., Probst, A., Roulet, M. and Isaure, M.P. (2008) Contamination of Surface Waters by Mining Wastes in the Milluni Valley (Cordillera Real, Bolivia): Mineralogical and Hydrological Influences. Applied Geochemistry, 23, 1299-1324. https://doi.org/10.1016/j.apgeochem.2007.11.019

[50] Piper, A.M. (1944) A Graphic Procedure in the Geochemical Interpretation of Water Analyses. Transactions American Geophysical Union, 25, 914-923. https://doi.org/10.1029/TR025i006p00914

[51] Pahimi, H., Panda, C.R., Ngassoum, M.B. and Tchameni, R. (2015) Environmental Impacts of Mining in the Volcano-Sedimentary Basins of Cameroon: Case Study of Artisanal Gold Mine Tailings (Betare Oya, East-Cameroon). International Journal of Energy, Sustainability and Environmental Engineering, 2, 5-15.

[52] Li, J., Li, F., Liu, Q. and Zhang, Y. (2014) Trace Metal in Surface Water and Groundwater and Its Transfer in a Yellow River Alluvial Fan: Evidence from Isotopes and Hydrochemistry. Science of the Total Environment, 472, 979-988. https://doi.org/10.1016/j.scitotenv.2013.11.120

[53] Zhao, Y.Z., Abuduwaili, J. and Feng, Q.J. (2015) Heavy Metal Contamination, Sources, and Pollution Assessment of Surface Water in the Tianshan Mountains of China. Environmental Monitoring and Assessment, 187, 33. https://doi.org/10.1007/s10661-014-4191-x

[54] Jdid, E.A. and Blazy, P. (2006) Métallurgie de L’or-Procédés. Techniques de L'ingénieur, 1, $16 \mathrm{p}$.

[55] Huang, X., Sillanpää, M., Gjessing, E.T. and Peräniemi, V.R.D. (2010) Environmental Impact of Mining Activities on the Surface Water Quality in Tibet: Gyama Valley. Science of the Total Environment, 408, 4177-4184. https://doi.org/10.1016/j.scitotenv.2010.05.015

[56] Plante, B., Bussière, B. and Benzaazoua, M. (2014) Lab Tofield Scale Effects on Contaminated Neutral Drainage Prediction from the TIO Mine Waste Rocks. Journal of Geochemical Exploration, 137, 37-47. https://doi.org/10.1016/j.gexplo.2013.11.004

[57] Gibbs, R.J. (1970) Mechanisms Controlling World Water Chemistry. Science, 17, 1088-1090. https://doi.org/10.1126/science.170.3962.1088

[58] Kamtchueng, B.T., Fantong, W.Y., Wirmvem, M.J., Tiodjio, R.E., Takounjou, A.F., Ndam Ngoupayou, J.R., Kusakabe, M., Zhang, J., Ohba, T., Tanyileke, G., Hell, J.V. and Ueda, A. (2016) Hydrogeochemistry and Quality of Surface Water and Groundwater in the Vicinity of Lake Monoun, West Cameroon: Approach from Multivariate Statistical Analysis and Stable Isotopic Characterization. Environmental Monitoring and Assessment, 188, 524. https://doi.org/10.1007/s10661-016-5514-X

[59] Youmbi, T.J.G., Feumba, R., Wethe, J., Ekodeck, G.E. and Marsily, G. (2012) Evaluation of Groundwater Suitability for Domestic and Irrigational Purposes: A Case Study from Mingoa River Basin, Yaounde, Cameroon. Journal of Water Resource 
and Protection, 4, 285-293. https://doi.org/10.4236/jwarp.2012.45031

[60] Mehto, A. and Chakrapani, G.J. (2013) Spatio-Temporal Variation in the Hydrochemistry of Tawa River, Central India: Effect of Natural and Anthropogenic Factors. Environmental Monitoring and Assessment, 185, 9789.

https://doi.org/10.1007/s10661-013-3291-3

[61] Ameh, E.G. and Akpah, F.A. (2011) Heavy Metal Pollution Indexing and Multivariate Statistical Evaluation of Hydrogeochemistry of River Povpov in Itakpe IronOre Mining Area Kogi State, Nigeria. Advances in Applied Science Research, 2, 33 46.

[62] Richards, L.A. (1954) Diagnostics and Improvement of Saline and Alkali Soil. U.S. Department of Agriculture, Washington DC, 160.

[63] Zhu, B. (2016) Natural Water Quality and Its Suitability for Drinking and Irrigation Purposes in the Jungar Basin, Central Asia. Journal of Civil \& Environmental Engineering, 6, 232. https://doi.org/10.4172/2165-784X.1000232

Submit or recommend next manuscript to SCIRP and we will provide best service for you:

Accepting pre-submission inquiries through Email, Facebook, LinkedIn, Twitter, etc. A wide selection of journals (inclusive of 9 subjects, more than 200 journals) Providing 24-hour high-quality service User-friendly online submission system Fair and swift peer-review system Efficient typesetting and proofreading procedure Display of the result of downloads and visits, as well as the number of cited articles Maximum dissemination of your research work

Submit your manuscript at: http://papersubmission.scirp.org/ Or contact jwarp@scirp.org 